\title{
Online Humour, Cartoons, Videos, Memes, Jokes and Laughter in the Epoch ${ }^{1}$ of the Coronavirus
}

\section{ABSTRACT}

From the onset of the indefinite deferral of our previously taken-forgranted lives, an abundance of humorous online cartoons, jokes, memes, videos and other satirical material relating to the COVID-19 outbreakand its consequences-has emerged. Humorous responses to this dire global pandemic proliferate irrespective of location, nationality, ethnicity, age, gender and/or socio-political affiliations. Against a background of enforced lockdowns, quarantine, and sometimes gross political ineptitude, with a mounting daily global death toll, humour referencing this scourge continues to blossom. This may seem counterintuitive or inappropriate at a time of heightened anxiety and fear apropos of an invisible killer-virus, known only in diagrammatic - and, ironically, aesthetically pleasingvisual form. Online humour evoking the COVID-19 crisis is expressed recursively via intertextuality referencing literary, visual, written, oral or other "texts." Interpictoriality is evident with memes that reconfigure renowned visual artworks. The internet enables copious discourse related to the COVID-19 eruption/disruption.

Embedded in this article are examples to support the article's theoretical basis, with intertextuality its major focus. Discussion follows, with speculation as to why humour, absurdity and wit are able to prosper in an environment of radical uncertainty and why joking about our parlous global predicament acts as a vital coping mechanism.

Keywords: viral humour, COVID-19 quarantine, online exemplars, analysis of specific works, validity of humorous discourse amidst a global pandemic.

1 I have used the word "epoch" throughout this article in reference to the SARS$\mathrm{CoV}-2$ virus outbreak because medical and scientific evidence points to the fact that this is only the beginning of a protracted period of time during which humanity will be living under the shadow of this pandemic. 


\section{INTRODUCTION: A BRIEF TYPOLOGY OF HUMOUR THEORIES, STYLES AND GENRES}

A brief summary of the major theories and genres of humour needs to be broached prior to discussion and analysis of the plethora of COVID-19 humour on the World Wide Web. For the most part, these theories and styles should not be regarded as discrete categories, but rather as intersecting one another in complexly ambiguous ways. In the final analysis, humour resists all attempts at definitive accounts or explanation.

It is largely accepted that humour, joking and comedy fall into four or five major theoretical categories, styles, genres, modes or approaches (see Venn Diagram for some of the major scholars and theorists in this field). The first of these is the Superiority theory in which people laugh at the presumed deficiencies and/or deformities of others. In the case of people with disabilities such "humour" can be toxic. The Superiority theory is one of the oldest (Western) theories of humour going back to Plato (thought to have lived c. $428 / 427$ or $424 / 423-348 / 347$ BC), later taken up by the Englishman Hobbes (1588-1679) and into the present day, often grafted onto the Incongruity theory.

Relevant here is also the German concept of Schadenfreude, a portmanteau word signifying the derivation of pleasure from someone else's or a group's misery, pain or misfortune. ${ }^{2}$ As with all of these theories, superiority and Schadenfreude are not necessarily humorous, but can often be malicious and very unfunny, especially from the target's perspective. Sadly, this kind of humour has become increasingly prevalent. Such humour often overlaps with the Incongruity theory, discussed below.

There are numerous Australian examples of sexist and racist jokes that fall into the Superiority grouping. In jesting mode sexist jokes can be ways of "taking the mickey" 3 out of the other gender. Such joking has been described as an "acculturating ritual" for some Australian men and women. ${ }^{4}$ Here is an example of a riddle posed by an Australian man to his mate, with three possible responses. The following discourse is underpinned by the unquestioned assumption of male supremacy and the objectification of women by some, but not all, Australian men: ${ }^{5}$

\footnotetext{
2 Translation: Schadenfreude—from Schaden: "harm” and Freude: “joy.”

3 The concept of "taking the mickey," derived from the British colonists, means teasing or (usually lightly) ridiculing another person or group. "Mickey" (sometimes "Micky") also has multiple different meanings.

For more on Australian humour as an acculturating ritual, see Milner Davis's “'Aussie' Humour and Laughter: Joking as an Acculturating Ritual."

5 In relation to early colonial Australia, male convicts, soldiers and settlers overwhelmingly outnumbered women in the colony. The gendered nature of Australian colonial society continued as male convicts were emancipated and more (mostly) male free
} 
Q: "Why is having a beer better than having a wife?"

A1: "Because you can enjoy a beer all month long."

OR:

A2: "Because hangovers go away."

OR:

A3: "Because beers always go down easy."

Often overlapping the Superiority theory is the Incongruity theory. As is the case with the Superiority theory it has a lengthy history in Western thought, from Aristotle through to Schopenhauer and Kant, and into the present day. It is based on the dissonance that exists between reality and/or what listener/s or viewer/s expect to hear, see or experience. The juxtaposition of two or more dissimilar phenomena sometimes occasions a pleasurable cognitive shift, often leading to laughter. An Australian example follows, largely founded on incongruity, the charm of which is enhanced by a childlike sense of playfulness:

An Aussie bloke was standing on a busy street corner in Melbourne, right next to the city's major train station. He'd tied a small rock onto a piece of string, which he was repeatedly twirling around his head. Another man walked up to the bloke and said, "What yer doing mate?" The man, who continued spinning the rock, replied, "I'm keeping the elephants away." The other man commented, "But mate, we don't have any elephants in Australia."

"I know," said the first bloke. "Effective, isn't it, mate?"

First related to me about a decade ago by an Australian friend (a woman), this joke attests to the Australian larrikin streak. Originally used as a term of abuse, nowadays "larrikin" has positive connotations, valorizing disdain of authority and social conventions. Larrikinism is widely regarded as a dimension of "the" Australian identity, mainly used as a descriptor for men, and occasionally for women.

The Englishman Terry Eagleton's point about incongruity humour that "the comic and the serious are clashing modes of cognition, competing versions of the nature of reality, not just alternative moods or discursive

settlers arrived, no doubt engendering the concept of mateship, which was from the outset an entirely male phenomenon. In recent years this has begun to change, but in Australian society a good deal more than vestiges of male supremacy remain evident. Further to this, the Australian Government Report of 2018-19 states that based on 2017 statistics, one woman was killed by her male partner per nine days and one woman in sixteen was subject to emotional abuse (also known as "coercive control") by her partner. This is undoubtedly an underestimation of the actual statistics in that many cases go unreported as a result of women's fear of retribution if they speak out. More recent statistics have emerged, showing that these figures have increased considerably as a result of the COVID-19 quarantine and lockdown restrictions. 
modes" (33) is alive in this joke. Humour is a breaker of conventions. In contemporary humour studies, it would be fair to say that for many humour scholars Incongruity theory has become a major focus.

Black humour, also known as Gallows humour, is by definition incongruous, in that it retails jokes alluding to persons dying violent deaths or similarly dark subject matter. Sometimes, but not always, these so-called "jokes" are offensive and inappropriate. While often off-limits, they continue to proliferate.

Here is a nasty example. After it became known that Australia's "backpacker murderer," Ivan Milat, had sadistically killed numerous young foreign backpackers hitchhiking around Australia, a swathe of jokes emerged based on his cruel and horrific crimes. After slaughtering his victims in the densely wooded Belanglo State Forest, Milat buried their remains at that site. It took considerable time for these burial sites to be discovered, and much longer to identify and charge Milat.

Offensive jokes came thick and fast. Here is one that was popular at that time:

Ivan Milat is driving through the Belanglo State Forest at twilight. Two British backpackers are sitting beside him on the front seat of his ute. The young women sense that something terrible is about to happen. Beside themselves, the girls begin to shake with fear. One says, "Ooh, we really don't like this place ... It's dark, it's cold, and I don't know why you've driven off the road into this horribly gloomy, dank forest." Milat responds, "Well, how do you think $I$ feel? I'm going to have to drive out of here alone."

Apart from the callous incongruity and apparent lack of fellow feeling displayed in this "joke," it also has an existential dimension, in that we all must accept the reality of eventual death. To laugh at death is to realize that we have escaped it, at the same time discharging our disquiet on that subject, because we haven't crossed the finishing line-yet.

There is also a psychological dimension evident in the previous example, connected to what is known, inter alia, as the Release or Relief theory of humour (see diagram below), which holds that dark humour involves psychological release or relief. Those of us who are capable of laughing at this joke have fortunately avoided the fate of the young men and women killed by this monster; our relief as survivors of such horror is expressed through the conduit of laughter. Freud distinguishes between innocuous joking and tendentious jokes, to which latter category the Milat example unequivocally belongs. ${ }^{6}$

6 For an expansion of the concept of tendentious joking, refer to the linguist Don L. F. Nilsen's article (see reference list). 
This brings us to a range of Psychological theories more generally, encompassing catharsis, relief and the release of pent-up emotion via humour that gives way to laughter, thus-in theory at least-reducing stress and saving psychic energy. As Eagleton writes, "The seventeenthcentury philosopher the Earl of Shaftesbury sees comedy as releasing our constrained but naturally free spirits" (10). Although Shaftesbury published his essay in 1709, it retains traction in the field of humour studies to this day. Shaftesbury coined the felicitous term "defensive raillery" in relation to such humour. Herewith is a contemporary exemplar leading into the influence of Freud whose cognate theoretical framework remains prominent. Two people of Jewish faith are chatting, when one man asks the other:

Q: Why do Jews always answer a question with a question? To which his friend replies:

A: I don't know, why?

A version of the release theory was later proposed and popularized by Freud, whose 1905 book Jokes and their Relation to the Unconscious (originally published in German as Der Witz und Beziebung zum Unbewußen), continues to exert considerable influence on humour theory to this day.

So why laugh? As Eagleton neatly puts it, "since humour involves a gratifying release of tension, which mimes the event of orgasm, even non-sexual varieties have subdued sexual overtones" (19). Laughter is thus also conceptualized as releasing sexual energy.

Returning to humour more generally, there is also a grouping around Existential and other Philosophical theories and beliefs that deal with the meaning of life-or its meaninglessness. For the most part, these are not "theories" per se, but reflect beliefs and each philosopher's attitudinal stance. For an example of existential humour, it is hard to go past thispossibly apocryphal-exchange between Jean-Paul Sartre and Albert Camus at their favourite Parisian restaurant, Les Deux Magots. They were discussing Camus's recently published book, Le mythe de Sisyphe, translated later as "The Myth of Sisyphus." The unfortunate Sisyphus offended the gods and was condemned to spend eternity pushing a large rock up to the summit of a hill only for it to roll down again immediately.

Sartre (reputedly) asked Camus, "When the Gods condemned Sisyphus to Hades to roll his rock up a hill eternally, was Sisyphus permitted to listen to music?"

Camus's (apparent) response was, "Yes! Rock and Roll, of course."7

7 This is a summary of Madame Irene Gaussen's account of this interchange. I do not know the source of this knowledge-it was delivered anecdotally along with the proviso that it may or may not have been authentic. 
We must not forget humour as a form of Play—linguistic play, visual play, mime, video play, sonic play, games, or sheer silliness. Play may encompass satire, or parody, or just plain good fun. Play can take the form of play on words, including slips of the tongue such as "Freudian slips" (Freud; Fromkin). There seems to be a level of inadvertency in some word play.

Spoonerisms (similar to "metatheses") exemplify word play, albeit inadvertently. The Reverend Spooner, a Christian minister and Oxford don (1844-1930) was said to transpose initial consonants of words in single sentences, thereby changing the sentence's meaning with humorous results. One example is "Work is the curse of the drinking classes" instead of "Drinking is the curse of the working classes." Another Spooner example replaces what was clearly intended to pay homage to the "Dear Old Queen," but was transposed to the "queer old Dean." While many Spoonerisms may be apocryphal, most of us will know someone who has done something similar and, when this happens, we try not to laugh. ${ }^{8}$

"Silliness" can also be a significant constituent of play, whether physical, cognitive, visual, oral or written. As Timms writes,

Silliness is a slippery concept: messy, unsettling and difficult to pin down. Its childish anarchy, its wilful disregard of social proprieties and constant frustration of our need for order put it outside of our accustomed way of perceiving the world, and thus dangerously in the orbit of anxiety, nihilism, and the grotesque.

Yet, for all that, it can be great fun. (1)

The emergence of the coronavirus has thrust humanity into that orbit, and in many of the examples of COVID-19 related humour there is a dimension of anarchic silliness, which acts as a salve, albeit temporarily. "Silliness" also has an existential and philosophical dimension, in that existentialism focuses on the liminal, including the nature of being and identity, anxiety and death. These are matters that underlie much of the humour under discussion in this article.

The porous nature of all of these quasi-artificial boundaries is noteworthy; more often than not they overlap. There are also semantic theories of humour-although it could be argued that there is necessarily a semantic element in all humour. Above all, to take liberties with Coleridge's dictum, humour requires a "willing suspension of humourlessness."”

8 For more on the possible underlying causes of this refer to Fromkin.

9 Coleridge's original statement alluded to literary works, including poetry, when he wrote of a "willing suspension of disbelief for the moment, which constitutes poetic faith." Here Coleridge was specifically referring to works of fantasy or the supernatural. Norman $\mathrm{N}$. Holland, in an article in which he revisits the same concept, provides an example of 
Intertextuality, too, matters in humour. Norrick, writing in 1989 before the internet loomed large, defined intertextuality as occurring "any time one text suggests or requires reference to some other identifiable text or stretch of discourse, spoken or written" (117). The now-omnipresent World Wide Web enabled an explosion of interpictoriality, although this well and truly preceded the immense social change resulting from digital technology. ${ }^{10}$

A cautionary note is needed. Despite the globalization of humour in our increasingly interconnected world, which has become evident during the global spread of COVID-19, Bremmer and Roodenburg repudiate attempts by scholars who endeavour to create overarching macro-theories to explain the aetiology of humour and laughter. They write that

a mistake common to all these attempts is the tacit assumption that there exists something like an "ontology of laughter," that humour and laughter are transcultural and ahistorical. However, laughter is just as much a culturally determined phenomenon as humour. (3)

The flawed assumption to which Bremmer and Roodenburg refer came into high relief in the case of the murders of staff working for the French satirical weekly, Charlie Hebdo. In January 2015 two Islamists fired on and killed twelve people employed by the weekly, injuring eleven others. Charlie Hebdo had a long history of robustly satirizing political and religious figures and events. The two murderers objected sufficiently to a depiction on the newspaper's front cover-a satirical cartoon featuring the Prophet Mohammed-to commit this barbarous act. ${ }^{11}$

The Charlie Hebdo incident exposed the accuracy of Bremmer and Roodenburg's prescient article while also speaking to the limits of satiric licence in our interconnected world. In the following section, examples of humour in this epoch of COVID-19 will be discussed, as will the question of the limits of humour. Is it true that in most of the Western world there is no subject matter too serious to become the theme of a joke? Many people seek to mitigate what could be interpreted as hostile joking by saying, "Well, it's just a joke." This leads us into examples of humour, to be discussed soon, as a global phenomenon that has become the strange but often entertaining bedfellow of the killer virus.

\footnotetext{
a humorous exchange in which he draws a specific parallel with humour as being subject to similar circumstances (1-3).

10 See Margaret A. Rose's excellent publication Pictorial Irony for more on preinternet iterations of interpictoriality.

11 For further information and analysis, see, for example, Połońska-Kimunguyi and Gillespie.
} 
It needs to be observed that, taken collectively, any and indeed all of these humour theories and attempts to generate a general, all-encompassing, humour theory is simply pie in the sky. Synthesizing all of these accounts of humour and factoring in the functions of humour and laughter will probably bring us as close as possible to achieving that elusive goal.

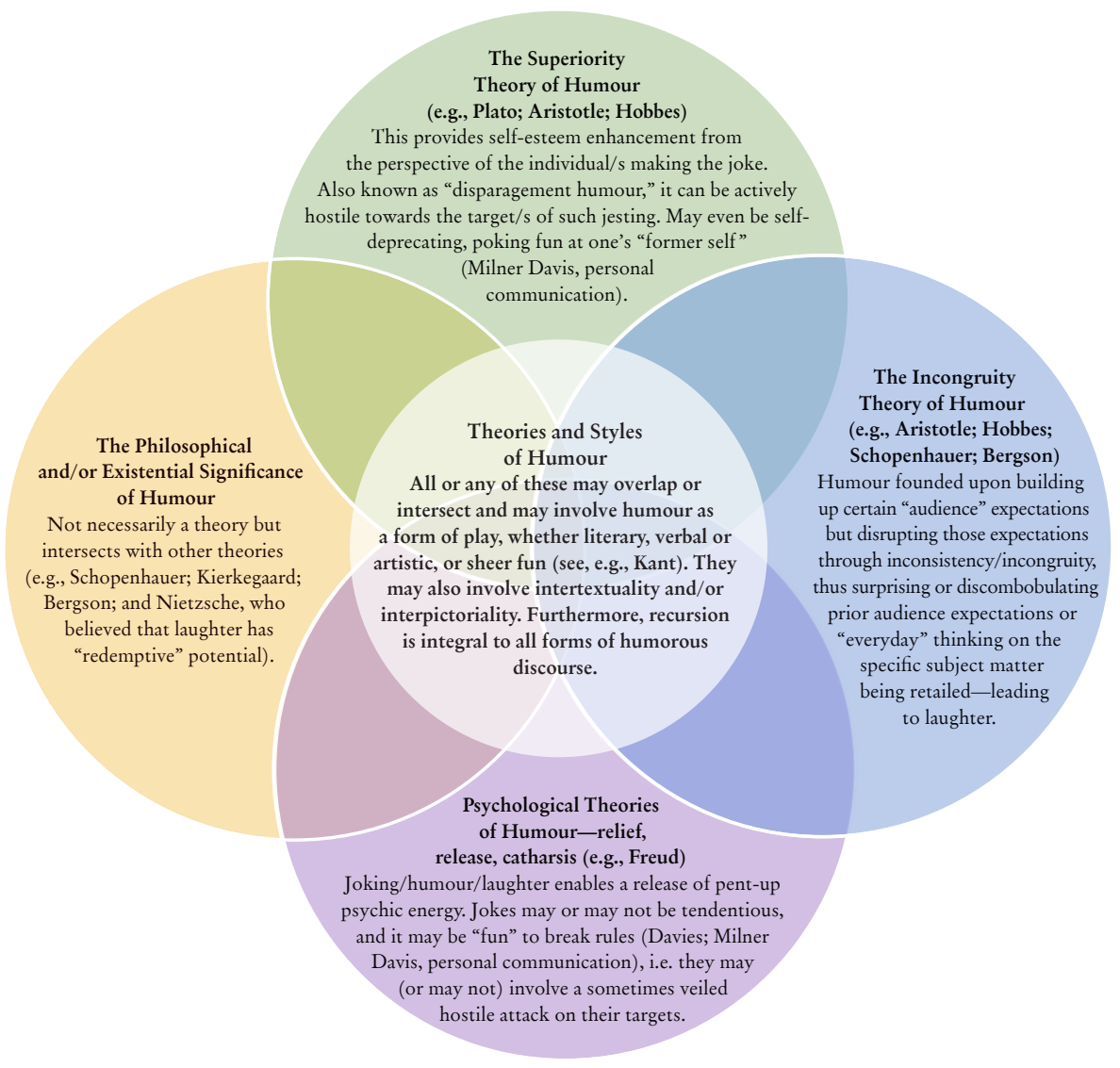

Fig. 1. Venn diagram. () Christine Nicholls, with thanks to Jessica Milner Davis.

Here the relationship of humour to laughter needs to be canvassed in brief. Laughing is not an undifferentiated phenomenon. As Eagleton writes, in the English language a range of different words distinguish modes of laughter. ${ }^{12} \mathrm{He}$ supplies examples that include, inter alia, cackling, chortling, snickering, guffawing, giggling, sniggering, chuckling and roaring

12 Note that is also the case with many world languages. For example, in French there are words including "rire" (a generic word meaning "to laugh"), "rigoler" (to joke), "glousser" (to chuckle or chortle), "ricaner" (to snicker or to snigger), and "caqueter" (to cackle)—and more. 
[with laughter] (Eagleton 1-5). For example, in Schadenfreude jokes, laughter-related words with derisory connotations, such as "sniggering" or "snickering," would normally be more apt descriptors than "giggling."

Given that the subject matter of the humorous examples in the next section relate to COVID-19, a global pandemic that could extinguish most or even all homo sapiens (respected scientists have stated that is entirely possible that an effective vaccine will never become available; see Bienkov) it becomes clear that the Incongruity and Release theories both play major roles, without necessarily precluding other humour theories or styles. For more on this, refer to Fig. 1 (see previous page) indicating the deep imbrication of all humour theories and styles.

\section{PART ONE: ANALYSIS OF CARTOONS FOCUSING ON THE COVID-19 PANDEMIC}

While this article features a selection of online humour, including jokes, memes, videos and cartoons in the epoch of COVID-19, the focus here is on cartoons. These exemplars are not only in recursive relationship/s with respect to the coronavirus itself and its ramifications, but recursion is integral to all humour, in that it needs an identifiable subject or a target. This is equally applicable to inter- and/or intra-textual or inter-pictorial joking, whether of a political or other nature, or makes reference to literary or visual artworks, specific events, modes of discourse, or to several fields simultaneously. As the mathematician David J. Hunter so felicitously puts it: "Recursion, see Recursion" (494).

\section{EXAMPLE 1: DAMIEN GLEZ'S CORONAVIRUS BIENFAITS (CORONAVIRUS BENEFITS)}

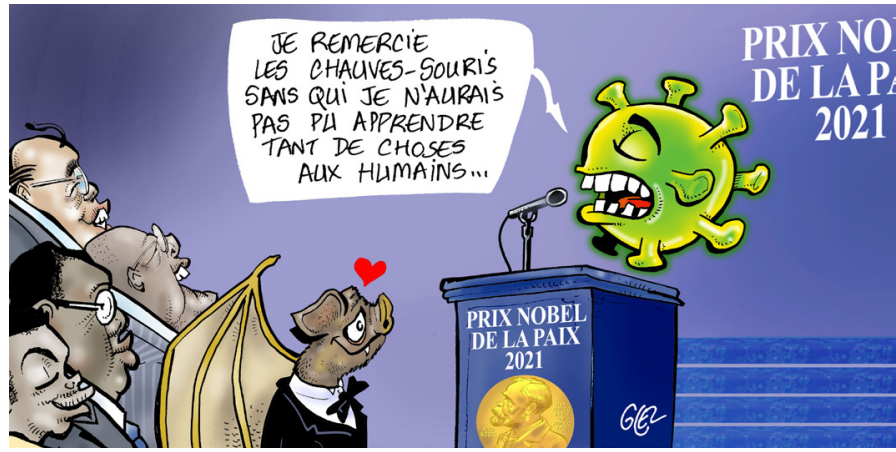

Cartoon published on Jeuneafrique.com, Burkina Faso. Published 26 March 2020, accompanied by an article written by Glez, titled "[Chronique] Top 10 des bénéfices inattendus du coronavirus" ("Top 10 Unexpected Benefits of the Coronavirus"). (C) Damien Glez and Jeune Afrique. 
Damien Glez is a professional cartoonist and writer who lives and works in Ouagadougou, ${ }^{13}$ the capital of Burkina Faso, an impoverished country in west Africa, currently on the brink of an inter-ethnic war (Malley), adding to the ironic poignancy of the "joke's" setting. In his intertextual, indeed, trans-textual cartoon Coronavirus Bienfaits (Coronavirus Benefits), Glez ingeniously filters the influence of the COVID-19 pandemic through the pre-existing model of the Nobel Peace Prize ceremonial awards evening.

Deploying darkly satirical irony, Glez depicts the victorious coronavirus hovering over the podium, addressing the assembled audience from a microphone. The virus declares that it "would like to express my appreciation to the bats without whom I wouldn't have been able to teach humanity so many things" ("Je remercie les chauves-souris sans qui je n'aurais pas pu apprendre tant de choses aux humains"). A tuxedo-wearing bat looks on admiringly, as does the small, clearly enthralled, African audience standing behind him.

The award of the Nobel Peace Prize to the coronavirus is an inspired example of merging trans-textuality with the incongruity theory of humour: Glez's cartoon challenges largely untested assumptions that there are only negative aspects of this virus. There have been benefits from the coronavirus, ranging from the lowering of toxic emissions that lead to climate change, the temporary reduction in aviation and certain longrunning international combat, and in some cases, a greater sense of our global interdependence and citizenship, although there is also evidence of the intensification of some pre-existing divisions.

Why base the cartoon on the structure and rituals of the Nobel Peace Prize? To begin, it is an event of global significance. Acceptance speeches for major prizes have been described as "mediated rituals" (see, for example, Dayan and Katz; Haastrup 127, 132). In the second chapter of their book, Dayan and Katz offer a typology of high-end, live media events that are broadcast widely, discussing these mediated rituals in terms of contests, conquests and coronations. The borders of these three types are to a considerable extent porous. The element of coronation, or "corona-tion" (groan!) is paramount in relation to Glez's choice of the Nobel Prize winner 2021.

What supports Glez's choice of the coronavirus as the winner? For starters, the pandemic is undoubtedly "winning" as it is nowhere near under control. Mass shutdowns in some parts of the world have tended

13 The link to this article is as follows: https://www.jeuneafrique.com/914768/ societe/chronique-top-10-des-benefices-inattendus-du-coronavirus/ (Society/ChronicleTop 10 Unexpected Benefits of the Coronavirus). The article itself is also worth reading, with sub-headings including "Ralentissement du réchauffement climatique" "The Slowing of Global Warming") and "Introspection philosophique et culturelle" ("Philosophical and Cultural Introspection”). 
to suspend rivalries and hostilities amongst groups within some nations, at least temporarily. For many individuals this continues to be a time of self-reflection and for stronger focus on our most important values, which have been forcibly downplayed to some extent over the years in our economically-obsessed, sell-sell workaday Western world. On the other hand, politicians who have lost traction as a result of being unable or unwilling to control the spread of the virus have fomented greater aggression. This has already become apparent in the political leadership of the United States, the increasingly dis-United Kingdom, China and Brazil (inter alia), whose political leaders have been lambasted via satirical or caricatural memes, cartoons and articles.

Humour and parody have the capacity to act as vehicles that undermine previously underexplored dominant beliefs and, on occasion, give voice to new and often uncomfortable truths that lead to positive change. In the Western world in particular, self-satisfaction and complacency about our-mostly-relatively comfortable ways of life, have been tested and challenged by the virus, owing to the need for quarantine and lockdowns. Paradigm shifts, for the most part, need a catalyst. This pandemic has already activated many of us to "differently think" about many things, and for some, this will continue post-pandemic. Glez's cartoon speaks truth to power: his neat reversal of everyday thinking about the coronavirus has been turned on its head.

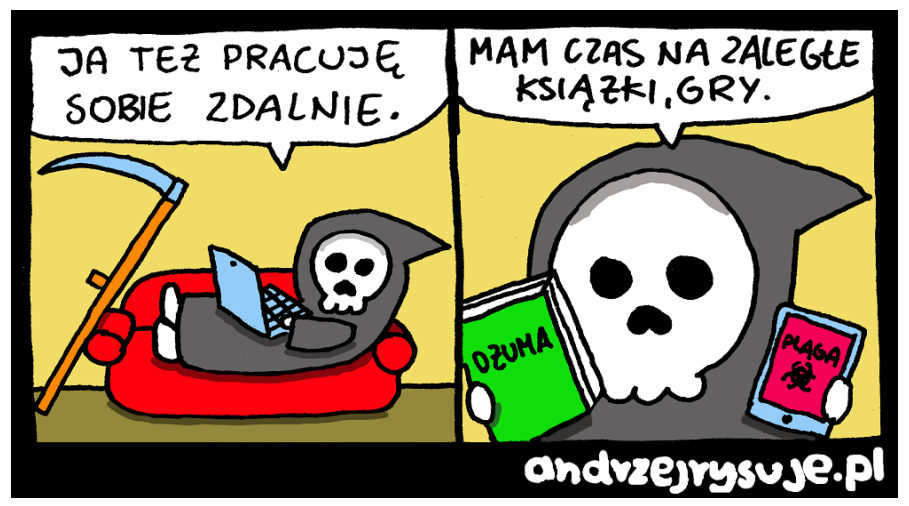

Andrzej Milewski's Kostucha mata (The Itsy-Bitsy Grim Reaper).

(C) Andrzej Milewski, 2020.

14 Sourced from his website at www.andrzejrysuje.pl ("Andrzej Draws") published on 20 Mar. 2020. 
In contrast with Glez's hard-hitting framing of the COVID-19 virus, the Polish cartoonist Andrzej Milewski offers, at least superficially, an apolitical, whimsical and lightly humorous take on the pandemic in his Kostucha mata (The Itsy-Bitsy Grim Reaper). In the first of the two frames, the diminutive Grim Reaper is recognizable by his symbolic cloak. This anthropomorphic version of a childlike Bearer of Death, depicted in a domestic setting, relaxed and comfortable, feet up on a sofa with laptop balanced on outstretched belly, downplays the seriousness of the pandemic. A scythe, the accoutrement denoting the Grim Reaper's metier of harvesting Death, is balanced on one side of the couch. It seems that the protagonist's work has now been initiated, and all that's necessary is to let it rip.

In the first frame, the itsy-bitsy Grim Reaper brags that he "work[s] remotely." In the second frame, Kostucha's right hand clutches Dizuma (the title of the Polish translation of Albert Camus's The Plague). "I've [now] got time [to catch up on] books and games" ("Mam czas na zaległe ksiązki, gry"), the little fellow avows in the next frame bubble.

In his left hand the wee Grim Reaper clutches a tablet or iPhone with the word Plaga written on it (the video game Plague Inc.) In terms of depiction, it is important to note that cartoons and other representational artworks both portray and betray not only the material circumstances of individuals, but also their psychological conditions. In this cartoon plague-related, death-themed reading matter and video games are sources of entertainment for the Grim Reaper. As Stephen Totilo puts it,

Plague Inc. is a sufficiently disturbing variation of the world we all live in now, if only we were the ones controlling the disease rather than fighting it ...

[T] he game's difficulty is determined by a complex algorithm that factors in, among other things, how frequently people in its virtual world wash their hands. Players win if humanity is extinguished. They lose if humanity finds a cure.

Many of us will find this not only morally deplorable, but given present circumstances, also an unhealthy form of entertainment, particularly for the young. On the other hand, Milewski's cartoon, seemingly focusing on confinement as a time of relaxation, consumerism, rest and recreation, underpinned by material prosperity, is no doubt comforting to children who may otherwise fear coronavirus.

It thus lacks the critical edge of Glez's work. Furthermore, there appears to be nil self-reflexivity in popularizing a game in which the ultimate 
objective is to wipe out humanity in entirety: gallows humour at its worst or best, dependent upon which side you sit in relation to the virus.

Unsurprisingly, China banned Plague Inc. in late February 2020, after the coronavirus had taken hold in Wuhan Province and had begun spreading far afield, describing its contents as "illegal," no doubt in retaliation to Trump's obdurate description of the virus as the "Chinese virus," and more recently as "Kung Flu." While the game has its strong detractors elsewhere in the world, there are also supporters, of whom a considerable number put forward a persuasive case for its "consciousness raising" dimension.

In part, the joke lies in the fact that the Grim Reaper may now stay at home and relax for an indefinite period of time. There is an element of irony in the joke, in that he's acting just like many of "us," staying at home during lockdown, taking it easy, entertaining ourselves. Moreover, while people are quarantined for safety reasons, they're still being scythed down: death's work is now carried out remotely, which is very handy for our little hero. Playing Plague Inc. as a relaxing "killing game," Mała Kostucha keeps his hand in for the time when he'll need to resume bis daily work.

This cartoon clearly fits into the category of dark humour. Death preceded by horrendous sickness and existential terror blends conceptually with what on the surface appears to be lightly entertaining discourse. As such, it takes considerable cognitive work to unpack the seemingly incompatible elements of this cartoon.

Suls offers an "incongruity-resolution model" of humour based on the idea that it is subject to a two-stage problem-solving process. Writing that if an individual is unable to identify what he describes as semantic, logical or experiential "rules" or dimensions (88) then s/he may miss the punchline and find the joke puzzling (or, I suggest, completely unintelligible). To this Suls further states that

in the ideal case, the problem solving will be successful and will retrieve the relevant rule that reconciles the joke parts. The punch line is then perceived to make sense, and the person "gets" the joke. When the apparent incongruity has been made congruous, the program has succeeded and will terminate; the humor has been understood. (88)

\section{EXAMPLE 3: FIONA KATAUSKAS'S CARTOON SOCIAL DISTANCING}

Fiona Katauskas, resident cartoonist for the liberal-minded Jesuit online Australian publication Eureka Street, whacks her audience with a double whammy of issues in her cartoon Social Distancing, a superficially tame but sharply satirical work. It is another case of the viewer/reader's expectations being dashed, insofar as the title leads one to anticipate a punchline relating exclusively to the coronavirus. 


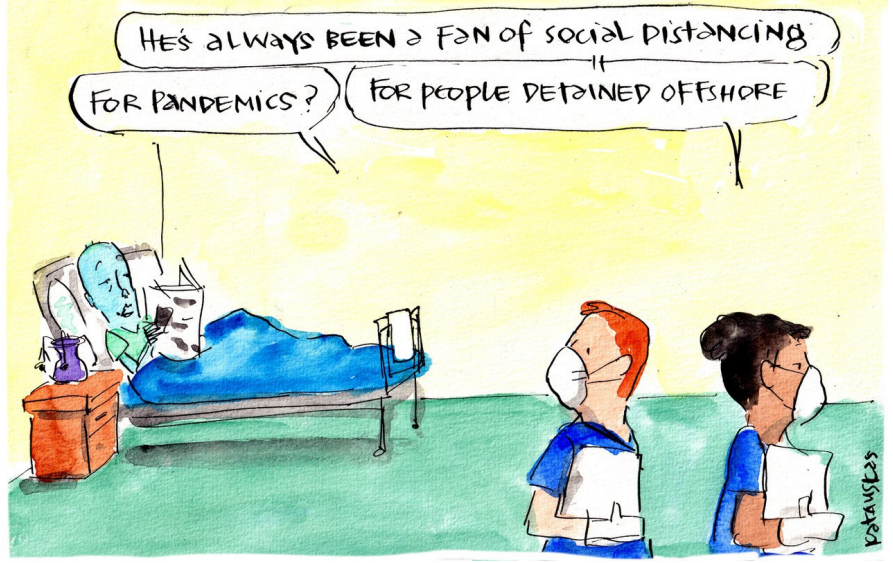

Published 17 March 2020, Eureka Street, www.eurekastreet.com.au.

(C) Fiona Katauskas and Eureka Street.

But no; in her written text, Katauskas skilfully and seamlessly turns the tables by referencing another form of confinement. Successive Australian Federal Governments have targeted refugees who arrive by boat. Some are sent back home to face almost certain death in the dangerous places from which they have fled, and others, lacking acceptable documentation, are placed on offshore islands in Nauru or New Guinea in prison conditions. Many incarcerated adults and children remain there indefinitely, presumably to live out their days.

A considerable number of detainees have been murdered or have committed suicide inside these detention centres. There is evidence that their jailers, a private company contracted by the Australian government, do not treat the internees with respect. Almost all inmates have mental health problems (see Glendinning for more on this).

The blue-faced man lying in bed is Peter Dutton, presently Australia's Federal Minister of Home Affairs, and arguably the country's most despised politician. A former policeman, Dutton is currently responsible for enforcing Australia's offshore detention laws. On the 13 March 2020 he was hospitalized with COVID-19. His distinctive elongated face, somewhat akin to the concave side of a spoon, with small, slitty eyes punched in, is a cartoonist's dream.

Katauskas's cartoons in general reflect Bergson's theory of humour as a social corrective, as does this one. But this cartoon also transcends that idea. Its brilliance arises from the sheer originality of the double entendre of the written text and its semantic ambiguity coupled with an inspired zeugmatic twist. 


\section{PART TWO: ANALYSIS OF ONLINE VIDEOS RELATED TO THE COVID-19 PANDEMIC}

\section{EXAMPLE 1: ANDREW COTTER'S OLIVE AND MABEL SERIES: GAME OF BONES}

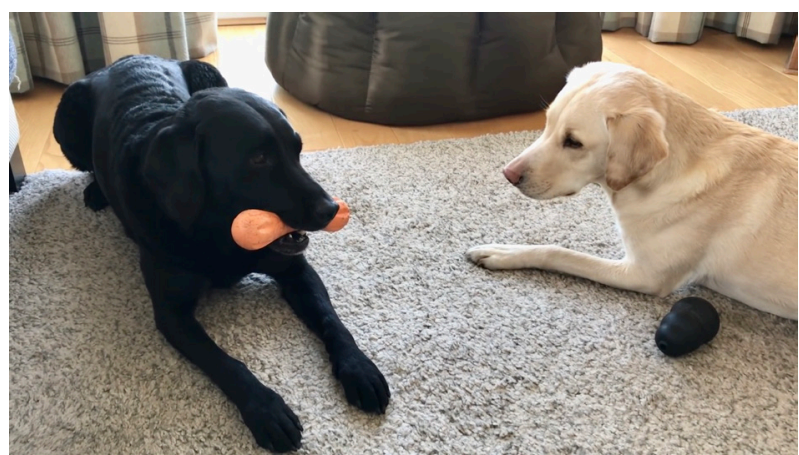

Video Still of Olive and Mabel. (C) Andrew Cotter. For full video, see: https://www.youtube.com/watch?v=f2BZNowCXws

For many years, Andrew Cotter has been a professional television broadcaster and sports commentator. For Australians, he is undoubtedly best known for his commentary on the Wimbledon tennis tournament, cancelled this year owing to COVID-19 restrictions. This has presumably led to a degree of ennui at home, as is the case with many of us. But Cotter's playful and obviously beloved dogs, Olive, a Labrador and the elder of the two, and Mabel, Olive's Golden Retriever playmate, came to the rescue, as did his own well-honed skills as a broadcaster.

These serve him well in the Olive and Mabel series. Cotter utilizes aural and visual techniques similar to those used in games played on courts or tables, that is, sports that take place between just two or four players in tightly circumscribed spaces-differing, for example, from golf, rugby or football, which are played by numerous players in larger spaces.

The patterns underpinning Cotter's Olive and Mabel's game evince a degree of similitude with tennis, badminton and table tennis, each of which are played as singles or doubles. While only a single camera is needed to cover an entire "court," this has changed in recent times to the use of several cameras, in order to track the trajectory of the ball, as well as closeups of the players' faces, or for event detection. The latter includes filming young and immature (mostly male) players throwing tantrums and destroying their rackets by smashing them into concertinaed wrecks. Olive and Mabel are much better behaved. In terms of the visuals in tennis and 
table tennis, there is a mixture of player close-ups, mid-views and "whole court" views, in other words an aerial view encompassing the entirety of the site, including spectators. Court commentary differs from that of soccer, rugby or hockey, which need more commentators and cameras to cover the number of players and the larger arenas.

Andrew Cotter's humorous videos-part parody, part pastichewould not have succeeded without his in-depth skillset, experience and expertise as a professional broadcaster along with his insider knowledge of this specific form of discourse. The tone of Cotter's commentary on the antics of Olive and Mabel is consistent with his live sporting commentaries, never deviating from the formulaic aspects of sports broadcasting techniques. This intimate, ostensibly deadpan quality plays a significant part in the humour in these doggie masterpieces. There is also an element of self-satire in Cotter's observations of his beloved dogs, and from this intertextuality the humour emerges. Another dimension of intertextuality is evident in Cotter's title: Game of Bones is a direct reference to Game of Thrones, in which epic battles are played out, although in this case the protagonists Olive and Mabel are literally only "playing."

Cotter's Olive and Mabel commentaries use the identical syntactic, lexical, semantic and thematic staples of his sports commentary. These short videos are simulacra of the "real thing." While the videos exist within a playframe, there is no dumbing or "species-ism" evident in Cotter's discourse. He refrains from "targeting" the dogs, who emerge as intelligent beings with individual characteristics. He clearly respects his canine companions.

As is common in the sports broadcasting genre, Cotter alleviates "duller moments" by introducing information or gossip about individual players. For instance, Olive's ability to outfox young Mabel is declining, and thus her competitive edge and playing career may—sadly—be drawing to an end.

Cotter's voice rises with unexpected turns of events, interspersed with equally urgent sotto voce remarks, changes in cadence, intonation and pitch, reaching a crescendo when the game swings from Olive's seemingly certain victory to a knife-edge situation. Cotter's charismatic commentary carries his enthralled audience towards the thrilling outcome. This is not a case of "playing" the audience: broadcasters of Cotter's ilk have played the specific sports/game/s themselves, enriching their métiers via intimate personal knowledge of specific skills, triumphs, troughs, hazards, and players' rapidly see-sawing emotions.

Tennis commentary conventionally remarks on moments when a player "wanders," losing concentration for a spell. This is evident in Cotter's commentary when the game nears the end, with an intensity of focus on the controlled rivalry of the two dogs over the coveted orange bone. Eventually Olive relaxes and releases her mouth-hold, giving the younger 
Mabel the edge to "win," with Olive clinching defeat from the jaws of victory. A previously mentioned feature of Game of Bones is the reference to the Game of Thrones. The latter's first story focuses on claimants competing for succession. Owing to its global success and formidably large and admiring fanbase, the Game of Thrones is now deployed by the media and others as a figure of speech relating to conflicts in various arenas. Given the equability and good-naturedness of both Olive and Mabel, this is another source of ironic humour in this online masterpiece.

Cotter's captivating Olive and Mabel videos provide viewers with an innocent and pleasurable release from the boredom of quarantine or lockdown as a result of the coronavirus. My response to these videos, along with many other dog lovers I know, accords with Samuel Johnson's definition of laughter as "convulsive merriment" (qtd. in Boston 61).

\section{This is Wilson. He is now working from home $\bullet$}

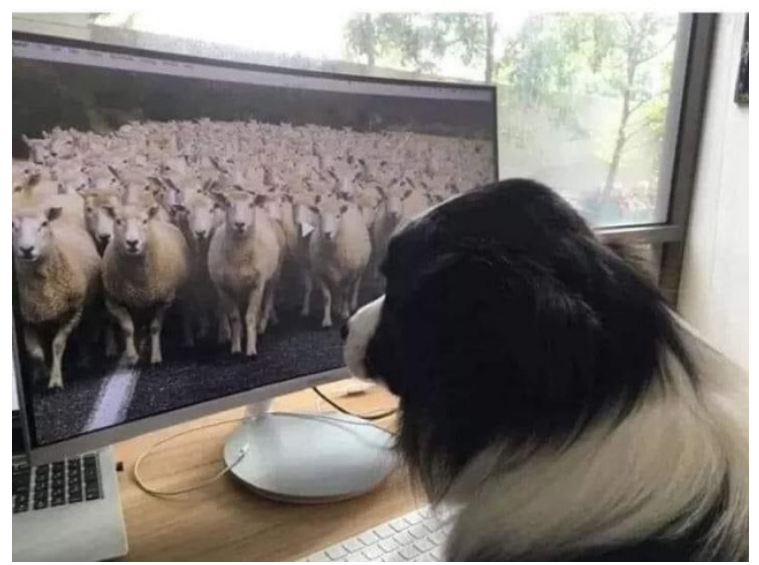

Courtesy Aussies Doing Things: @aussiesdointhgs. To view the video go to https://youtu.be/ixZBzU9xghQ, “Sheep Dog Works from Home,” @Obi.wong. kenobi.

It is timely to introduce Wilson the Sheepdog, currently working from home and doing equally well as Olive and Mabel during confinement. Unlike many, he has retained his job. Not only that, Wilson has developed newly-acquired high-level IT skills.

Although not as conceptually complex nor as skills-based as Cotter's Olive and Mabel series, this short video, which embraces a decidedly 
anthropocentric philosophical view of judging animals' worth based on what they are able to do for humans, either as workers or food, the charismatic canine protagonist in this photograph and video provides a counterpoint to Cotter's canine-themed virtuosity. The humorous incongruity in Wilson arising from this amusing one-liner is based on the impossibility of carrying out certain kinds of work from home amidst a pandemic.

\section{EXAMPLE 3: A PRESCIENT VIDEO CLIP FROM YES MINISTER}

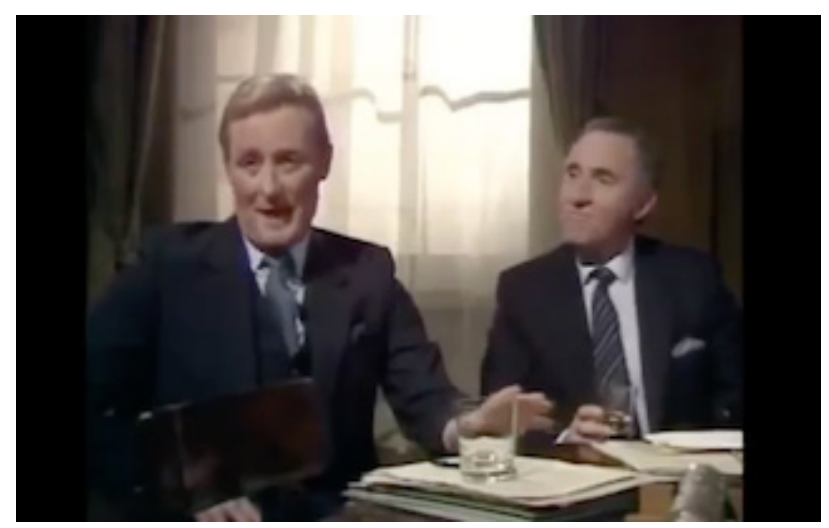

Image courtesy of YouTube. Full video available at:

https://youtu.be/EcqIC5LT6fo

This satirical excerpt from the Yes Minister series showing British politicians bumbling their way through stages of a crisis - in an episode made decades before the onset of the COVID-19-provides an uncannily well-matched account of Prime Minister Boris Johnson's extemporaneous responses to coronavirus in the UK, while also providing insight into the functioning of successive British governments when difficulties arise, regardless of political persuasion.

In this episode and in real life as COVID-19 emerged there was almost total political inaction on the part of senior members of the current British government, including the Prime Minister. This prolonged period of improvisation, stasis and inertia has now marginally improved, but the dithering, the denials, and the Tory government's erratic approach to the virus and their abrupt flip-flopping continue. This highlights their chronic inconsistency of approach. A seeming lack of foresight and failure to take the current pandemic seriously (initially at least, and to some extent, still the case) amounts to a denial of the possible catastrophic consequences of the virus, which has given rise to a death toll of over 50,000 British people at the time of writing. 
The remainder of this brief Yes Minister clip-a stage-by-stage revelation of a serious mishandling of an unnamed crisis-closely resonates with what has been unfolding in the UK apropos of the coronavirus. The dialogue is a very British form of conversational humour, offering those who viewed this Yes Minister episode years ago a strange sense of déjà vu as we witness similar political stuff-ups today and, worse, law-breaking on the part of the current Prime Minister's Chief Adviser, Dominic Cummings. This was followed by the hypocritical disavowal of Cummings of any personal malfeasance when it was revealed that he had blatantly breached the quarantine and lockdown regulations issued by the government.

In this irony-laden short video clip of a humorous verbal exchange between the British Prime Minister and his staffer, the scriptwriters were dead accurate. It is an example of life following art, reversing the norm. A satirical meme (see Example 4 in the following section on memes) of Boris Johnson's front-page photograph on the fictional magazine Vague exemplifies Johnson's dilly-dallying and frequently changing positions in his public pronouncements on how the British citizenry ought to behave apropos of coronavirus restrictions. This testifies to his indecisive and extemporizing approach, leaving lives at risk and NHS medical staff working in unacceptable conditions without sufficient PPE (personal protective equipment, including masks and so on) (Lintern). The situation in Trump's America is even more dangerous for Americans in general and specifically for health professionals (Farmer).$^{15}$

EXAMPLE 4: DAY 6 IN QUARANTINE

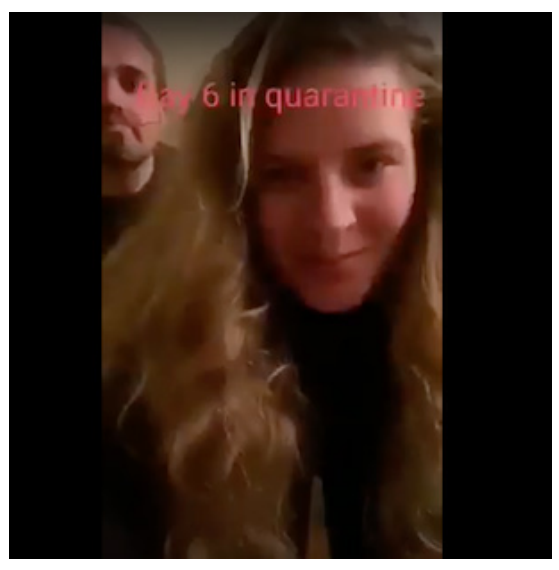

With thanks to Jill Rendell. For full video, go to: https://youtu.be/7Ateq6AhuvA

15 Note that while both the Lintern and Farmer articles cited were published earlier in 2020, the same situation continues to apply in the USA and UK at the time of writing (August 2020). 
This simple but effective video might be dubbed "Horse-Play," because exuberant "play" and joyous silliness (Timms) is at its heart. Exemplifying the critically-endangered art of "making one's own fun," this ability has been a game-changer, enabling people to function optimally during quarantine or the lockdowns imposed by the pandemic, both physically and psychologically.

An important point to be made here is that there is only a thin line between everyday life and play, humorous or not. This young couple are getting on with their lives during quarantine while playing.

Play enters our lives in multiple ways. It ranges from playing sports, board games or chess, music, playing with our children, grandchildren, friends or pets, or by simply playing the fool, and "love" and sexual play, when mutual and non-coercive. Play is an integral part of human life, and also the case for animals (de Waal). It appears to have a biological basis (see, for example, Groos, “The Psychology of Animal Play”). For the most part the word "play" connotes entertainment, leisure and pleasure.

Playing begins in early childhood; it is a means of self-expression and a way of learning how to impose and follow rules, while developing cognitive and motor abilities (Groos, The Play of Man), ${ }^{16}$ along with perseverance. Most parents are delighted to see their children happily absorbed in playing games that they've dreamed up. It not only enhances children's academic learning, but enhances their socio-emotional growth and ability to form positive relationships (Ginsburg). Importantly, the ability to play in childhood becomes a habit that serves us well in adulthood, as does a sense of humour. There is also evidence that habitual play provides children with the ability to cope with past and present problems, building resilience, a critical factor into adult life, which is definitely required in the present circumstances.

Another significant attribute of play is interactivity with others-its social dimension (Ginsburg). According to Orthner, play also relieves tension, while enhancing intimacy between partners (also see Betcher). This is congruent with the Freudian concept of humour as a means of releasing apprehension or tension.

The early $20^{\text {th }}$ century Swiss scholar Groos, whose scholarship is particularly relevant to this video, viewed humour as based on either superiority or "contradiction," which I understand to be synonymous with incongruity. Distinguishing between receptive play and productive play, Groos focused specifically on sound, including rhythm and pitch.

16 Groos also wrote extensively about the play of other animals, although most humans reject the idea of being animals, believing this is to be an erroneous belief ("The Psychology of Animal Play”). 
He noted that playing certain games "excites laughter in all beholders" (Groos, The Play of Man 85).

In a section titled "Playful movement of the bodily organs" Groos wrote that when dancing is accompanied by music, and especially when related to courtship or love, "an exciting movement-play ... possesses ... the magic power of abstracting us from commonplace existence and transports us to a self-created world of dreams" (The Play of Man 91). He commented explicitly on the "intoxicating power of [rhythmic] movement" in dance (The Play of Man 91). Groos also made the point that when the tempo quickens in dance or music it becomes more exciting, a phenomenon that is experienced even in infancy. Groos further explained that when babies and children, who love repetition, hear the same word pronounced differently they will laugh. The young couple's productive bodily play combined with the music and variations thereof, are crucial to the success of this simple idea.

Their video also evokes a rich and established tradition in vaudeville in which two actors perform in horse costume. ${ }^{17}$ The young "stars" of this homemade video draw upon this tradition, knowingly or not.

Extraordinarily, this young couple have created their video wearing their own clothes while exercising their bodies within a confined space. At the end of their gig, the young woman, whose long, thick hair represents the horse's rhythmically swishing tail, collapses into contagious laughter, bringing a smile to her partner's face (see Provine for more on contagious laughter). Most important is their self-sufficiency and creativity in improvising their way through what for many people is regarded as a boring loss of time. Their anarchic silliness should inspire others to "loosen up."

\section{PART THREE: MEMES: FROM POSTER ART TO MEMES}

The word "meme" was coined by Richard Dawkins in pre-internet days (1976). Akin to genes, memes self-replicate, sometimes exponentially, but Dawkins defined them as being culturally transmitted and replicated, not genetically. Since the advent of meme-generators, memes have been mutating uncontrollably, sometimes into their thousands or millions.

Online memes are arguably the offspring of poster art, an earlier form, a populist democratic art including printed lithographs or screen-prints. Twodimensional poster art is traceable as far back as Japanese woodblock prints, originally popularized by Hokusai (1760-1840). In Europe, printed lithographs

17 Among the most celebrated were Morton and Mayo, who performed between the 1920s and into the 1940s. Pansy the Dancing Horse was a-if not the-crowd pleasing act. They used an elaborate costume and a "sidekick" presenter, usually an attractive young woman. See Pansy the Dancing Horse, Vimeo (Amy Savarese), 5 Dec. 2015. 
from the mid- $19^{\text {th }}$ and into the $20^{\text {th }}$ century ranged from reproductions of fine artworks through to rhetorical and/or humorous subject matter, including sexualized imagery. In many cases, poster art images were appropriated from European Old Masters, to then be sold in large numbers and hung in living rooms around the world. Poster art was typically used for advertising films, sports events and disseminating political views. Posters also began to become a common form of street art. In the western world, political posters came to the fore during the First and Second World Wars.

In the Australian context, there is general consensus that political poster art had its heyday in the 1960s, continuing into the late 1980s. ${ }^{18}$ In 1970s, Australian posters proliferated during the Vietnam War. Young men (often still in their teens) were conscripted and forced to participate on the side of the United States; some died and others became invalids. Conscientious objectors were jailed.

Anti-war posters began to appear on buildings. ${ }^{19}$ State governments responded with their own posted message "BILL POSTERS WILL BE PROSECUTED,” issuing fines to offenders. Young protesters created a humorous riposte, going out in the middle of the night with paintbrushes, writing “WHO IS BILL POSTERS?”, also a play on Ayn Rand's repeated refrain in her capitalist diatribe Atlas Shrugged, "Who is John Galt?", turning the tables on those they viewed as oppressors with blood on their hands.

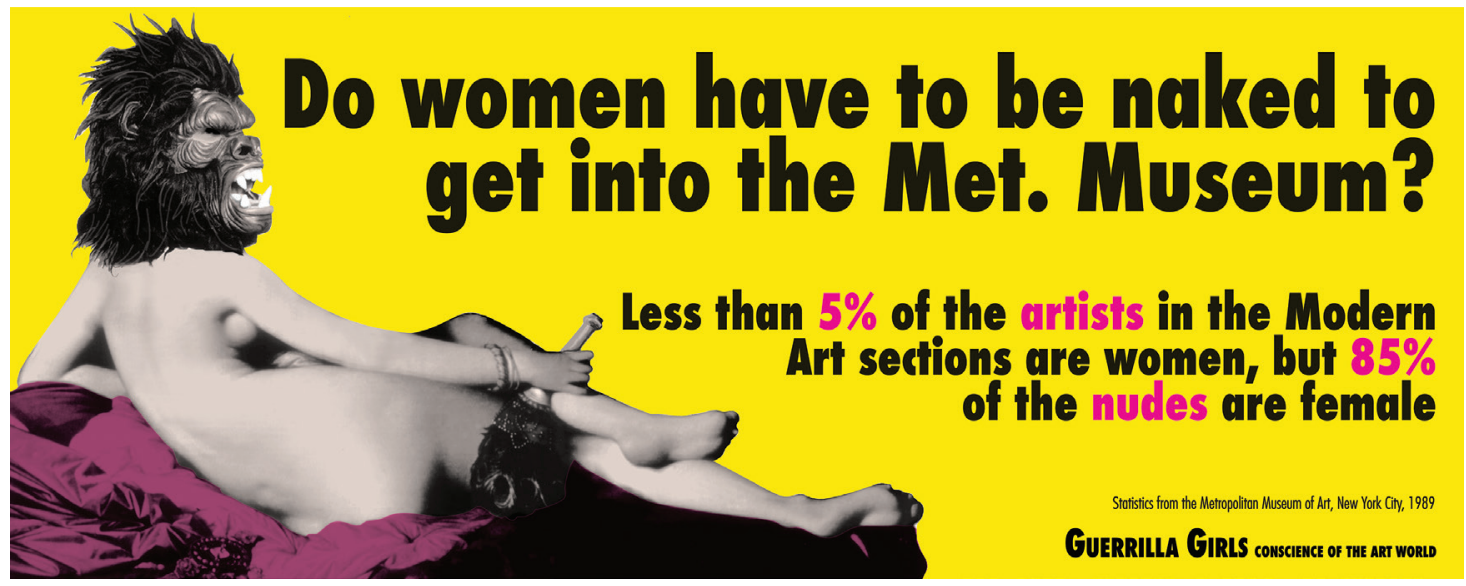

Fig. 2. Do Women Have to Be Naked to Get into the Met. Museum? Digital print, size variable, 1989. Copyright (C) Guerrilla Girls, courtesy guerrillagirls.com.

18 As discussed, there were also many posters created during WW1 and WW2 supporting the war effort, with a smaller number critiquing it.

19 I was living in Sydney at that time and this political action was an exciting time for a young person. 
From the mid-to-late $20^{\text {th }}$ century, poster art became increasingly assertive in its political messaging. In the early days of Gay Liberation, and throughout Second Wave feminism, poster art flourished. While virtuoso artworks by the Guerilla Girls (see previous page) were influenced by advertising and street art, now they are being acquired by many of the world's major art galleries, museums and private collectors. ${ }^{20}$

The internet has largely, although not entirely, replaced poster art, usually taking the form of memes. The contemporary, everyday use of "meme" has come to mean the reproduced and captioned images created and posted on the internet en masse daily.

As Shifman writes, "defined as cultural units that spread from person to person, memes were debated long before the digital era. Yet the Internet turned the spread of memes into a highly visible practice, and the term has become an integral part of the netizen vernacular" (362). The spread of memes is like the diffusion of the coronavirus itself. They "go viral."

Like genes, memes undergo "mutations" over time. But, as William McGrew writes in a review of Susan Blackmore's The Meme Machine, there are "obvious differences" between memes and genes. McGrew demonstrates that genes and memes are not strict analogues when he writes that "genes (apart from viruses) move only vertically, from one generation to the next, via meiosis. Memes also move vertically, but more often horizontally, within generations. (Lamarckian as well as Darwinian evolution!)" (23).

Examples follow, each closely related to two of the world's most famous and recognizable classical artworks. Both artworks were extensively caricatured prior to onset of the COVID-19 pandemic.

\section{EXAMPLE 1: "MUTATING MEMES" RELATED TO CLASSICAL ARTWORKS}

Transforming great artworks into humorous memes relating to the coronavirus aligns with Freud's view of humour as a psychological coping mechanism and a means of controlling a fear response. In the case of both of the memes discussed here, Munch's The Scream has been domesticated, which could be regarded as a form of epistemological violence. ${ }^{21}$

Laughing at something that may well wipe all of us off the planet is also incongruous - if not downright inappropriate and tasteless—but laugh

20 Note that "Guerrilla Girls works are not limited editions, [but] are reproduced at sizes from 8 inches [20.3 centimetres] to 100 feet [30.5 metres]. They are in hundreds of museums, owned by thousands of individuals" (personal communication with Kath Kollwitz on behalf of Guerilla Girls, 3 Jun. 2020).

21 As a result of meme generators, people can now add to or alter the original image and/or text, further modifying the original work, in ways that may not meet (or in the case of deceased artists, may not have met) the approval of the work's creator. 
we do. Admittedly, The Scream, of which Munch created four versions, is underpropped by a nightmarish vision which resonates to some extent with our current global circumstances.

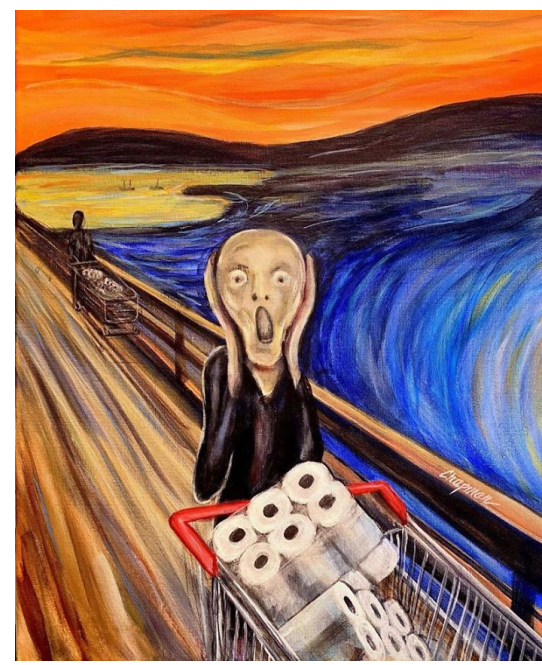

1a. Meme based on the Norwegian Expressionist Edvard Munch's 1893 The Scream, originally titled in German as Der Schrei der Natur (The Scream of Nature) and known as Skrik (Shriek) in Norwegian. Many thanks to Gail Carnes for assistance with IT. Original meme courtesy Chapman ${ }^{22}$ and boredpanda.com.

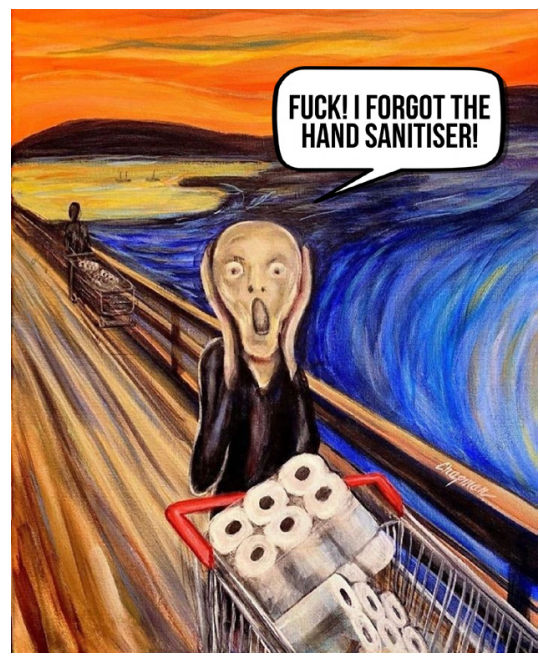

1b. A parody meme by Chapman of The Scream, modified (dialogue added; anonymous).

22 This meme is signed "Chapman," to whom I have gone to great lengths to contact, without success. It was uploaded onto the boredpanda.com website in early April 2020. 
Analogously to genes, memes range from harmless to noxious and are able to proliferate exponentially but, in contrast to genes, memes also often function as effectual rhetorical devices, as shown by the examples below.

EXAMPLES 2A AND 2B: THE CREATION OF ADAM
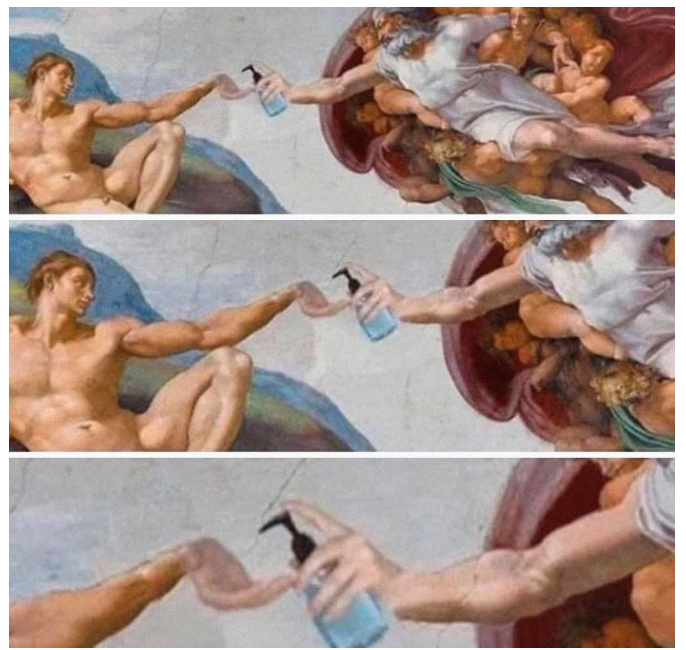

2a. Untitled, God Providing Adam with Hand Sanitizer, courtesy boredpanda.com.

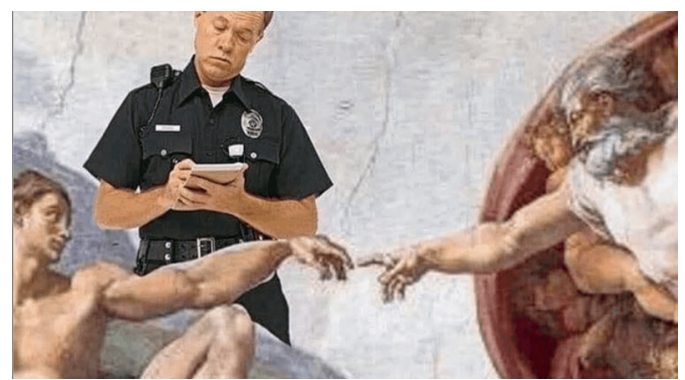

2b. Untitled, anonymous (this meme appears to have been partially imitated and modified from the previous example).

These witty, ironic and allusive memes are coronavirus-themed adaptations of Michelangelo's The Creation of Adam (Creazione di Adamo, 1512), a fresco on the ceiling of the Sistine Chapel in Rome. The proximity of the almost-touching hands of God and Adam caused consternation at that time.

In the first, God is providing Adam with a "helping hand," offering him hand sanitizer - a delectably humorous act of kindness, befitting the 
Almighty. But from a contemporary Christian standpoint, some viewers may regard this second intertextual meme as a tad more tendentious in terms of its subject matter, despite the fact that it was probably plundered from the previous "God and Adam" meme, then doctored by a meme generator.

To adumbrate on the possible reason why many renowned classical artworks have become subject to "meme-ification," it could be surmised that use of celebrated, instantly recognizable and populist images has the capacity to bring reflected glory to the meme creators or Instagrammers: a kind of celebrity by proxy.

\section{IF TRUMP HAD BEEN CAPTAIN OF THE TITANIC CORONAVIRUS EDITION \\ 1. The iceberg is a hoax \\ 2. We won't hit the iceberg \\ 3. We barely touched the iceberg \\ 4. Nobody could've seen the iceberg \\ 5. These deaths mean my plan worked \\ 6. I'm the best captain ever \\ OCCUPY DEMOCRATS}

3a. Original meme: If Trump Had Been Captain of the Titanic, early March 2020. Image courtesy of Occupy Democrats, courtesy Omar Rivero, Cornell University, Founder at Occupy Democrats.

While this meme focuses primarily on Trump's braggadocio, bluster, selfcontradictory messaging and his habitual resort to obfuscation, the meme that follows, a modified appropriation of the above, amplifies the original by explicit reference to Trump's policy reversals and blathering talk in his mostly abstruse, semi-literate tweets, often virulently attacking individuals and groups that are not regarded as fellow travellers. This often comprises bitter streams of invective, leading to greater social polarization within his nation.

The second meme (see below), a more sophisticated modification of the previous example is also a veiled topical allusion to his presidential style, covering similar territory as the first, but focusing more sharply on the erratic nature of and the glaring inconsistencies in Trump's jibber- 
jabber and the perilous capriciousness that sullies the man's capability for authentic leadership, i.e. Trump's Erratica.

While both memes are underpinned by rhetorical purpose, satirizing Trump's self-serving farrago of excuses and his tendency to escape criticism by befuddling his "followers," neither meme is as lightly amusing and benign as they may seem. Trump's self-serving, see-sawing modus operandi is designed to divide and conquer. The majority of his pronouncements are divisive in nature; he works on an "us" and "them" basis, and has no problem with being hated. That is used to entrench and shore up his support, a tactic used to split the nation and demonize the Democrats. Trump thrives on oppositional politics, the more hostile the better because he uses it to solidify his political base and to metaphorically snuff out adversaries.

Neither meme vilifies Trump. Instead of hurling direct abuse at him as per many Facebook and Twitter posts, these memes ridicule him. It could be argued that holding him up as an object of ridicule has a greater capacity to damage Trump and his devotees than "hating" him, which is more easily dismissed. On the other hand, ridiculing him transforms him into an incompetent and mendacious "target" (Davies), by way of attacking his selfhood, his being. Narcissists don't like personal attacks, veiled or otherwise.

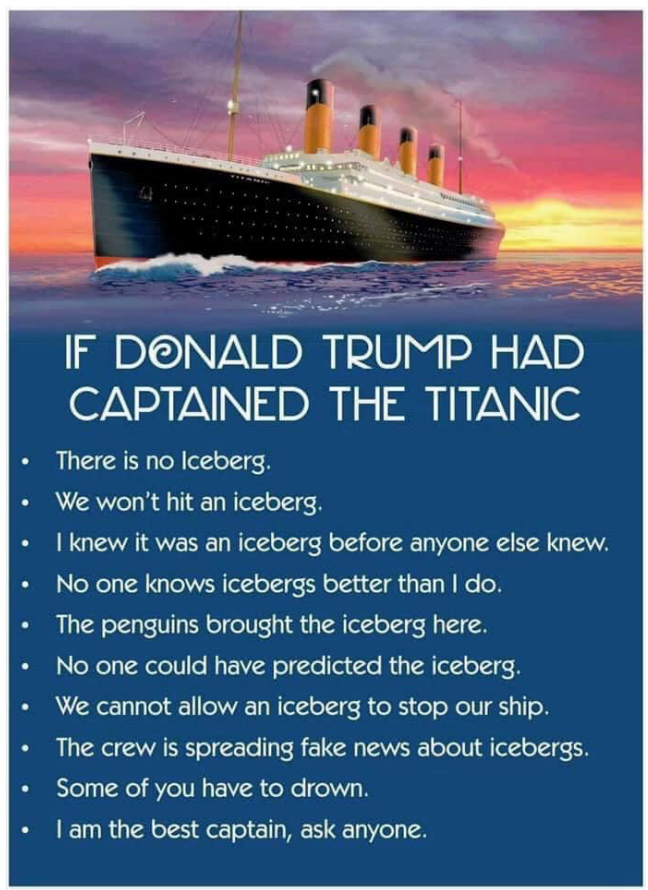

3b. If Trump Had Captained the Titanic (modified by anonymous "memester"). Reddit, April 2020. 
These metonymic representations of Trump as the incompetent captain of a doomed and ultimately sinking ship is a wonderful sleight of hand on the part of their creators, and a clever means of sidestepping backlash from the thin-skinned, litigious subject of this meme. In the United States, the spread of the coronavirus and its death toll have a good deal less to do with the virus itself, but is the consequence of ill-considered human behaviour, including Trump's. It is the direct result of his wayward, authoritarian stance. While both memes are amusingly satiric in nature, the humour is unlikely to fuel real social change: his minders will undoubtedly ensure that these don't reach Trump's desk.

\section{EXAMPLE 4: BORIS JOHNSON MEME}

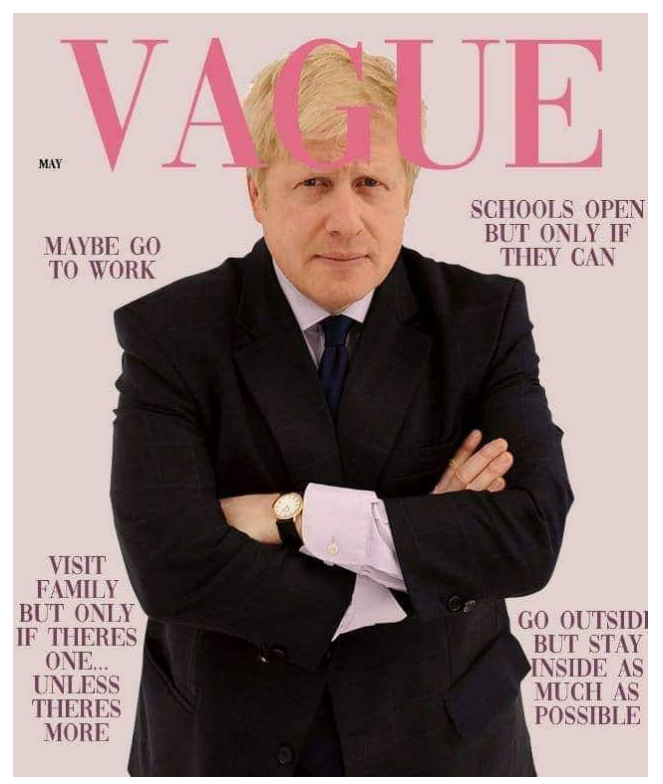

Boris Johnson on the front cover of Vague, May 2020. Anonymous. Please note that the author has made extensive efforts to establish the provenance of this meme without success.

The ironic meme above appropriates and riffs on the high-end Vogue fashion magazine's front cover pages, featuring Boris Johnson as "vague.” It appeared in May 2020. At that time EuroNews reported that "Boris Johnson [had been] grilled on [his] 'vague' UK coronavirus lockdown advice." ${ }^{\text {"23 }}$ It

23 See Sandford and Hurst "Boris Johnson Grilled on 'Vague' UK Coronavirus Lockdown Advice.” The British prime minister's "stay alert” message has been criticized by politicians and members of the public and caused tension with UK nations. 
represents Johnson's shilly-shallying and frequently changing positions in his public pronouncements about how the British citizenry ought to conduct themselves during coronavirus restrictions. This image presents Johnson as smartly-attired and unusually well groomed, which is rarely the case.

In a December 2006 edition of The New York Times Caroline Weber described Vogue as "the world's most influential fashion magazine." ${ }^{24}$ Vogue is pitched at an aspirational audience with a desire for wealth, luxury, style, fashion and, ultimately, celebrity. This intertextual meme's incongruity not only satirizes Johnson's scattergun, less-than-ideal approach to curbing the coronavirus ("Trump-lite"), but also provides a witty commentary on his frequently scruffy appearance, and less-than-prime-ministerial vestimentary code-he often appears in obviously unironed or ill-fitting suits, the lapels of which sometimes exhibit visible dandruff-topped off by a shaggy mop of unkempt hair. ${ }^{25}$

\section{EXAMPLE 5: WINNIE THE FLU}

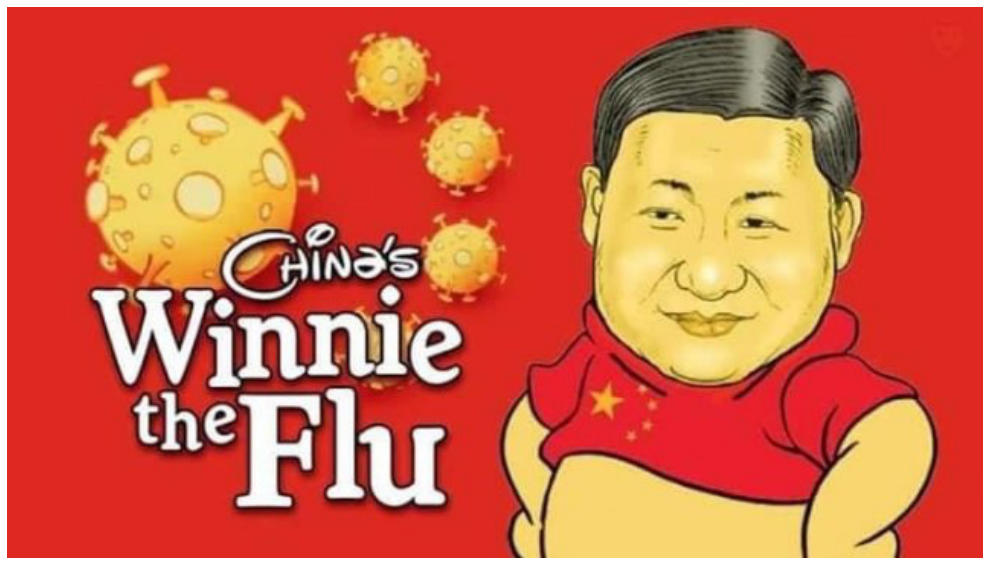

Winnie the Flu, 9 April 2020, from Weibo (anonymous). Reproduced by Technology and Social Change (TaSC) Research Project—at the @ShorensteinCtr. on Media, Politics and Public Policy (Harvard University), "As When Memes Go Viral," Winnie the Flu—When Memes Go Global by TaSC, https://link.medium. com/Ac3CNhY1g7, 24 March 2020 (accessed the same day).

24 See Weber.

25 Ordinarily I would not bring this to readers' attention, but felt it necessary in this case because women holding political (or other high-profile leadership positions) would never escape negative commentary were they to adopt Johnson's sloppily insouciant approach to personal grooming and fail to adhere to a standard of dress code befitting a Prime Minister. In this regard, politics and society in general are riddled with hypocrisy. 
The following meme shows President Xi standing in front of a Chinese flag on which its sparkling golden stars have been transformed into the instantly discernible imagery of the coronavirus. President Xi's apparently benign smile along with his rather round, fleshy face, and jowl and neck laxity, brought about his nickname "Winnie the Pooh," which has stuck for some years now, although it is now illegal to use it in China (Halfpenny).

While the repression of the negative handling of "foreign" coronavirusrelated media coverage in China is extreme, in equal measure the American President, Donald Trump, the British Prime Minister, Boris Johnson, and the Brazilian President, Jair Bolsonaro, also do their utmost to obfuscate, minimize or outlaw negative media coverage of their own inadequate practices to contain the coronavirus. Trump and Bolsonaro (in particular) have supressed the truth of the effects of the virus on their populace to the maximum extent possible in their so-called democratic nations. When ridiculed or satirized, they are equally as thin-skinned and touchy as the powerful Chinese President Xi Jinping.

EXAMPLE 6: JEAN-CHARLES GESLOT'S LA PESTE (THE PLAGUE)

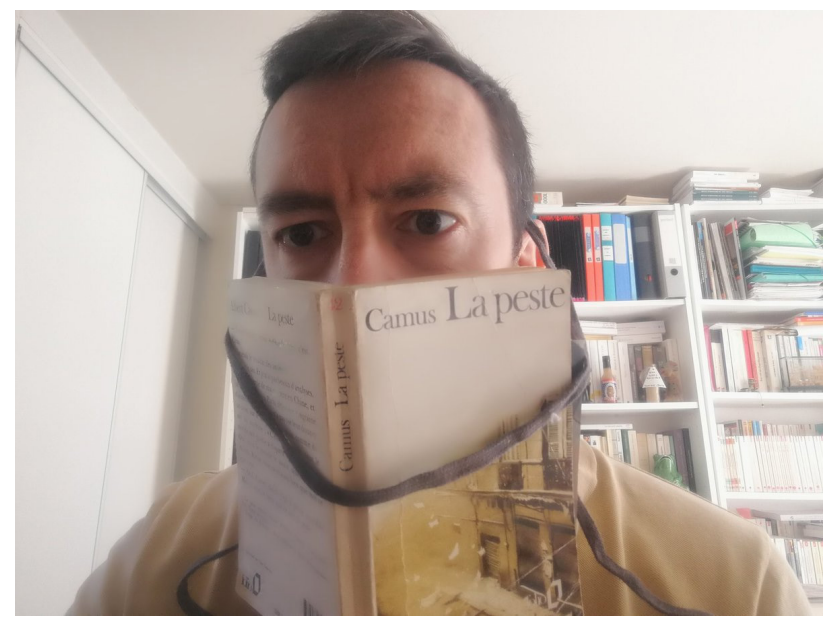

Jean-Charles Geslot's La peste. (C) Jean-Charles Geslot.

Geslot's La peste is a decidedly cerebral intertextual meme which, by contrast with the preceding examples, manifests no political partisanship. This inter-discursive meme is the most sophisticated-while at first sight, modest-meme in this section. It comprises a "selfie" of Geslot, who works in the Contemporary History Department at the UVSQ in France. 
In this wryly entertaining, philosophical meme, Geslot has donned a copy of the book La peste (Camus) to wear as a face mask, apparently to ward off the coronavirus. While there is a dimension of humorous self-deprecation in this image, that is transcended by the image's implicit critique and subversion of magical thinking based on the relationship between the COVID-19 virus, its causes, potential antidotes, and death rates. ${ }^{26}$ This has resulted in some individuals and groups taking absurd "preventative" measures in the hope of obviating the risk of contagion.

The largest group of "addressees" ${ }^{27}$ of Geslot's meme most likely belong to a specific (global) humour community, which includes classically educated readers. That group will appreciate this as parody, partly based on the sheer lunacy of using any book as a facial mask..$^{28}$ The inappropriate use of any book for this purpose, regardless of its content, unequivocally places this meme within the incongruity theory of humour. The appreciative laughter that follows is also undoubtedly cathartic.

Norrick asserts that there are

fundamental differences between witty allusions and parody as traditionally defined. In alluding, the performer challenges the audience to recognise the source text, so intertextual jokes are aggressive toward the audience ... Allusive jokes use a brief intertextual reference

26 As Jacqueline Rose wrote: "By the end of March [2020], monthly sales of the UK Penguin Classics edition [of The Plague] had grown from the low hundreds to the midthousands and were rising (they are now up 1000 per cent) ... One of the things The Plague conveys is that, at the very moment we appear to be taking the grimmest reality on board, we might also be deluding ourselves. Counting is at once a scientific endeavour and a form of magical thinking. It can be a way of bracing ourselves for and confronting an onslaught, and at the same time a doomed attempt at omnipotence, a system for classifying the horror and bundling it away... We take all the measures there are to be taken, adequate and inadequate according to where and who we are. And we wait."

In Camus's novel, it is only when men start dying, as opposed to hundreds of rats, that the public begins to understand. And even then, only slowly. The announcement of 302 dead citizens in the third week of the epidemic does not speak to the public imagination: "The plague was unimaginable, or rather it was being imagined in the wrong way" (qtd. in J. Rose). As Camus had put it in his composition notebook of 1938, the people are "lacking in imagination ... They don't think on the right scale for plagues. And the remedies they think up are barely suitable for a cold in the nose. They will die" (qtd. in J. Rose). Rose further emphasizes the notion of magical thinking in relation to The Plague.

27 See later discussion on Bakhtin's concept of addressivity, which is relevant here, and to many other parts of this article.

28 Research shows that even surgical masks are to some degree ineffective. As Natasha Turak writes, “[e]xperiments by a team in Hong Kong found that the coronavirus' transmission rate via respiratory droplets or airborne particles dropped by as much as $75 \%$ when surgical masks were used.” This research was undertaken by leading microbiologists at the University of Hong Kong. Cloth masks are less effective. See Turak. 
concentrated in a punchline, to which the audience must respond with laughter, whereas parody presents an extended caricature of some source text, which evokes a play frame conducive to but not requiring laughter. So parody cannot be viewed as an expanded allusive joke. (Norrick 117)

Apropos of this delightful and timely meme, I would dispute Norrick's hardline differentiation of parody and allusion. Geslot's self-parody (using a book as a mask to dispel infection) and his "witty allusion" in merging the subject matter of Camus's masterpiece with the COVID-19 outbreak are not at odds with one another, but rather, reinforce the multiple layers of humour in this splendid example. The book's title, La peste (The Plague) obviates any ambiguity with regard to the literary allusion, with Geslot's self-parody drawing attention to the non-efficacy of any book as an effective mask. Hence there is no "hostile challenge" on the part of the "performer" towards the audience to recognize the source or subject matter of the text, regardless of whether they have read it or not. Thus, allusion seamlessly merges with parody. The result affords this meme with a triple-barrelled impact, comprising allusion and self-parody cocooned within a play-frame (dressing up at home and taking a selfie).

While some may not recognize the parodic layering of Geslot's meme, those who do will understand what Nash describes as "parodic intention" (89). As Michael Clark writes,

The question "What is humour?" has exercised in varying degrees such philosophers as Aristotle, Hobbes, Hume, Kant, Schopenhauer and Bergson and has traditionally been regarded as a philosophical question. And surely it must still be regarded as a philosophical question at least insofar as it is treated as a conceptual one. (Clark 20)

Finally, as one reviewer of this article commented,

[ $t$ ] he demeanour of the masked man, particularly the sombre gaze of his averted eyes, conveys unease. This is seemingly underpinned by the realisation that the relationship between fiction and reality has become, at best, tenuous, and at worst, no longer exists. In these extraordinary times fiction has become reality and contemporary "reality" is akin to fiction. ${ }^{29}$

The source of the man's presumed anxiety is the fact that we can no longer hide behind the "cover" of fiction. This is a parody of the increasingly unstable relationship between "reality" and the current plethora of

29 Colette Mrowa-Hopkins, personal communication with the author, 3 Jul. 2020. Also see Totilo. 
spurious or illusory understandings of what constitutes reality or what used to be called "truth," fuelled by certain political leaders (see Rabin and Cameron; Kessler; Jackson) and widely disseminated by particular media corporations. The man behind the mask is well-aware that hiding behind this book won't fend off the coronavirus, accounting for his palpable angst. By this means Geslot's brilliant use of satiric irony humorously subverts the artistic endeavour of humankind..$^{30}$

The mask thus acts as a metaphor, representing the contradictions that arise between reliable medical and scientific know-how about the coronavirus and its implications for society, as opposed to fallacious ideation that has little or nil basis in reality (see forthwith Trump's Happy Hour). It accords with Camus's comments on the plague cited by Jacqueline Rose in footnote 26, and has been borne out by President Trump's 4 July 2020 previously cited mendacious speech, stating that $99 \%$ of coronavirus cases are totally harmless, and his more recent statement (7 August 2020), claiming that children are virtually immune to coronavirus (Jackson).

EXAMPLE 7: TRUMP'S WALL

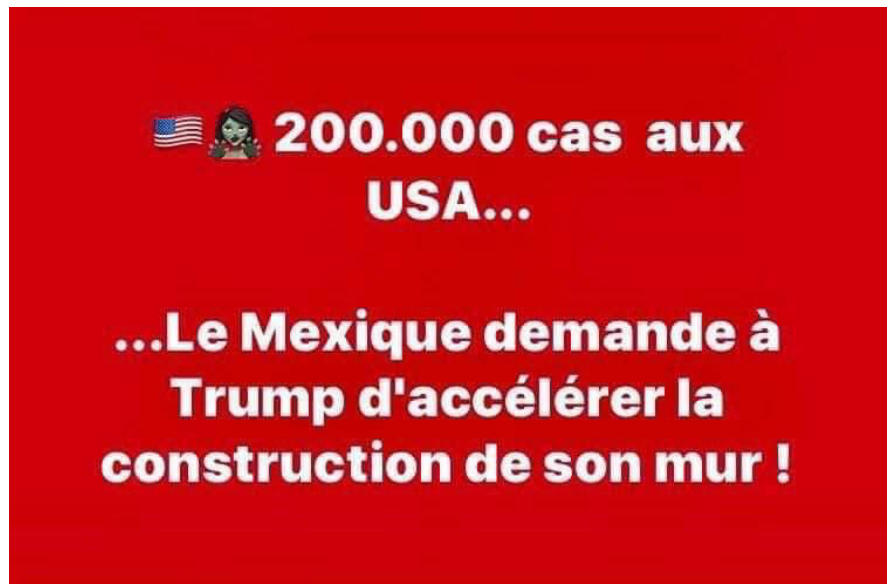

Trump's Wall, meme, March 2020, courtesy rofl ("Roll on the floor laughing"). ${ }^{31}$ English translation: "200,000 cases in the USA ... Mexico asks Trump to get cracking on building his wall!" Please note that since the appearance of this meme the number of cases of coronavirus and the death toll in the US has burgeoned.

This text-only meme is more typical of memes generally. Like jokes and, to some extent, riddles, memes are frequently comprised of two parts: a "set-up"

30 For more on ironic subversion in humour, see Veale.

31 Available at https://rofl.fr/le-mexique-demande-a-trump-daccelerer-la-constructiondu-mur/ 
scenario describing a specific event, situation or widely known fact, followed by a punchline, ${ }^{32}$ often unexpectedly incongruous, as evinced by this firstrate French meme.

Cleverly, this trans-textual meme also draws attention to Trump's numerous ego-inflating thought bubbles, in this case his desire to build an impenetrable wall designed to keep Mexicans out of the United States.

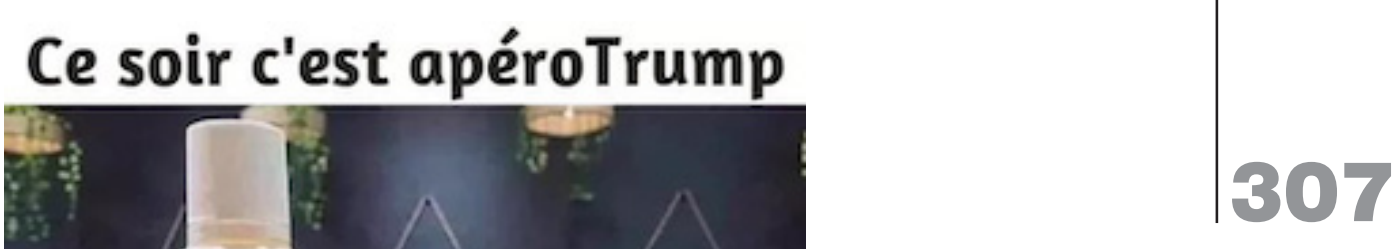

Ce soir c'est apéro Trump (English translation: Trump's Aperitif Tonight or Trump's Happy Hour Tonight). Belén Rivas, courtesy Raoul Hedebouw.

With narcissistic fervour, Donald Trump, an individual with nil background in science or medicine, has been providing gratuitous advice to the masses, recommending medicines and folk cures that he wrongly believes will provide protection against the coronavirus. Among these transgressions, he has strongly promoted hydroxychloroquine, an ineffective, dangerous and potentially fatal drug when taken by healthy people, many of whom are unaware of its dangers. Trump claimed to be taking a course of this drug himself, an assertion to be taken with a grain of salt. Worse still, he

32 This applies to many memes, including visual and verbal jokes. Sherzer defines a joke as "a discourse unit consisting of two parts, the set up and the punch line" (216). 
advocated that people inject household disinfectants containing bleach into their bodies as a form of immunization. ${ }^{33}$

The Deutsch Presse-Agentur (DPA) global news agency reported that ingestions of bleach dramatically increased after Trump publicly advocated these poisons as a means of eluding the virus. As DPA reported,

Concerns about the ingestion of household cleaning products spiked in April when President Donald Trump during a news briefing that disinfectants, "by injections inside or almost a cleaning," could some day be used to clean the lungs of people infected with COVID-19. (DPA 8)

The DPA further reported that a survey found "a staggering 18 per cent of participants confessed that they had applied cleaning agents to their skin," and 4 per cent admitted that they had either actually drunk or gargled bleach (DPA 8).

This background provides added piquancy to the meme, the dark humour of which at first sight seems merely absurd. Underlying it is a hostile, targeted parody of the conduct of a powerful and dangerously out-of-control individual.

\section{Varför umgås Snövit bara med sex dvärgar just nu?}

\section{Prosit sitter i karantän...}

\section{English Translation:}

Why is Snow White now only looking after six dwarfs?

Because Sneezy is in quarantine..

Meme courtesy of Humorbibeln, https://www.humorbibeln.se/, with thanks to Ann-Britt Sand, Jane Mears and Christopher Marcatili. Note that originally the dwarf named here was "Wheezy," more recently "Disney-fied" as "Sneezy." In actual fact in this context the Swedish word "Prosit" is a metonym, meaning something close to the German expression "Gesundheit," a way of wishing good health to a person who sneezes in one's presence.

33 Note that after the backlash to Trump's so-called "advice" to inject bleach as a prophylactic measure, he tweeted that he was only being "sarcastic." For more information, see "Coronavirus: Outcry after Trump Suggests Injecting Disinfectant as Treatment,” https://www.bbc.com/news/world-us-canada-52407177 
This Swedish example of a text-only meme has emerged from the oral tradition of the riddle, with its question and answer structure, and reprised as a meme by the addition of its veiled reference to the COVID-19 pandemic. It is one of only a handful of coronavirus memes suitable for young children.

As Georges and Dundes state,

in order to define the riddle structurally, it is first necessary to delineate a minimum unit of analysis. It is here proposed that the unit be termed descriptive element... A descriptive element consists of both a topic and a comment. (113)

Enunciating this, a riddle almost invariably introduces a topic in the form of a question and an answer that may be deduced via specific reference to the topic/comment and/or a response that sometimes, but not always, takes the addressee into an entirely different domain. Georges and Dundes further classify riddles as oppositional or non-oppositional, writing that "in literal non-oppositional riddles, the riddle referent and the topic(s) of the descriptive element(s) are identical" (113-14). This applies to the Snövit meme, with one exception, in that the answer requires the addressee to infer an additional topic (the coronavirus) which, while topical, is quasi-non-oppositional, in that COVID-19 is not explicitly stated in the answer.

As stated earlier, many examples of humorous memes that make reference to human behaviour during the pandemic are simply betterdressed jokes, one-liners followed by a punchline. As such, many do not bear over-analysis. It is also the case that for "consumers" of humorous memes, specific social, political or literary knowledge, or expertise in the visual arts, are de rigueur for the reader/viewer's comprehension and/or appreciation of their humour. In this regard all joking is subject to semantic limits.

As Giselinde Kuipers avers, rather than examining the formalist characteristics of jokes, humour needs to be understood as "primarily ... a social phenomenon"; Kuipers therefore proposes "a working definition of humor in which the social aspect is prominent: I see humor as the successful exchange of joking and laughter. Humor in this definition is viewed as an exchange involving a number of people" (7).

This approach to humour and joking as social phenomena is one that I strongly endorse: but where does it leave us as isolated individuals in lockdown or quarantine who are able to laugh out loud at humorous memes or other forms of humour? The answer to this is, I believe, that we 
feel that we belong to an "imagined community" 34 of like-minded people who similarly delight in the joke's relevance.

The Bakhtinian concept of addressivity is significant here, and in all examples provided in this article. Bakhtin writes that,

An essential (constitutive) marker of the utterance is its quality of being directed to someone, its addressivity. As distinct from the signifying units of a language-words and sentences - that are impersonal, belonging to nobody and addressed to nobody, the utterance has both an author (and, consequently, expression, which we have already discussed) and an addressee. This addressee can be an immediate participant-interlocutor in an everyday dialogue, a differentiated collective of specialists in some particular area of cultural communication, a more or less differentiated public, ethnic group, contemporaries, like-minded people, opponents and enemies, a subordinate, a superior, someone who is lower, higher, familiar, foreign, and so forth. And it can also be an indefinite, unconcretized other (with various kinds of monological utterances of an emotional type). All these varieties and conceptions of the addressee are determined by that area of human activity and everyday life to which the given utterance is related. Both the composition and, particularly, the style of the utterance depend on those to whom the utterance is addressed, how the speaker (or writer) senses and imagines his addressees, and the force of their effect on the utterance. Each speech genre in each area of speech communication has its own typical conception of the addressee, and this defines it as a genre. (95)

In the case of internet memes and other forms of visual or oral humour, addressivity is not exclusively oriented to listeners, but also to readers or viewers. Such addressees need to be glossed collectively as a more or less differentiated public, or as an indefinite, unconcretized other as per Bakhtin's account. Parenthetically, this also explains why the internet is inclined to degenerate into a site of struggle and divisiveness, as often the identities of the addressees and their opinions are an unknown quantity.

\section{EXAMPLE 10: FORMER JAPANESE PRIME MINISTER SHINZŌ ABE ALLOWED ONLY TWO MASKS PER HOUSEHOLD}

Japanese politicians have access to as many masks as they want or need. So the former Prime Minister Abe's announcement that only two masks would be allowed per household did not go down well with ordinary Japanese people, especially given that many Japanese live in multigenerational

${ }^{34}$ This expression was coined by Benedict Anderson in a different context; see Anderson. 
households. Social media spawns a profusion of successful and humorously hostile memes targeting politicians or other social power-brokers, and this case is no exception. As Knight writes, "Satire is not, on the whole, private and domestic. It tends to be concerned with public issues and public examples of those issues" (7).

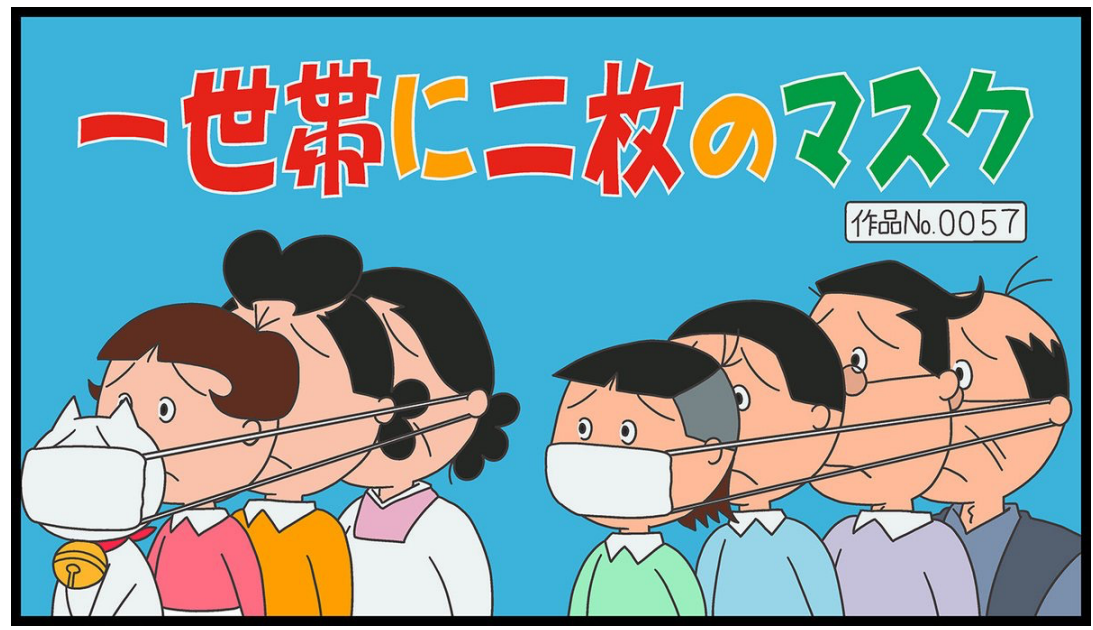

English translation of Japanese caption: “Two masks per household." Credits: Tomohiro Osaki, "Abenomask? Prime Minister's 'Two Masks per Household' Policy Spawns Memes on Social Media," Japan Times, Tokyo: https://www.japantimes. co.jp/news/2020/04/02/national/abe-two-masks-social-media/\#.XuiyKy3L2L8, accessed 16 June 2020. With thanks to Adrian Francis, Australian documentary filmmaker living in Tokyo.

\section{In relation to Abe's policy, Adrian Francis explains that}

The two-mask decision was widely condemned on social media as tonedeaf and ineffectual. I'm a one-person household and received two masks. Multiple-person households received the same. [This meme] is [also] funny because the family featured is from the long-running Japanese animation Sazae-san. They are a seven-person and one cat household. Someone on social media (Twitter?) created this meme to show how ridiculous the whole thing is. (personal communication with the author, 17 June 2020)

Such social inequity is equally applicable to hospitals and aged-care homes elsewhere in the world where masks were or still are in short supply, including in Australia for a lengthy period of time, where masks were shared between two or three patients (personal communication from an Australian aged-care manager) and the same applies in India up to and including the present day. 
EXAMPLE 11: SWEDISH BUS STATION

\section{SWEDISH BUS STATION BEFORE GORONAVIRUS}

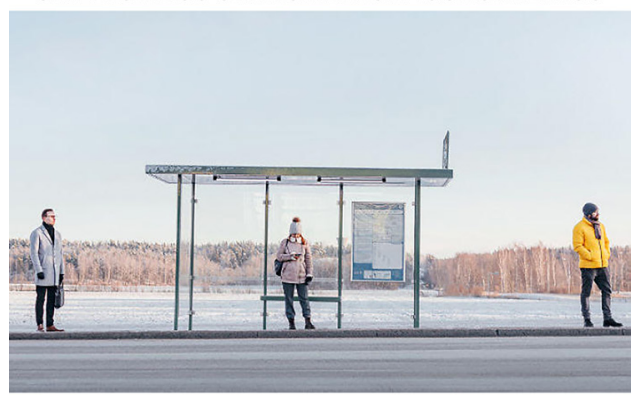

SWEDISH BUS STATION AFTER CORONAVIRUS

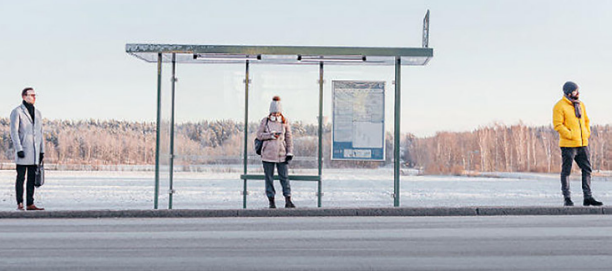

Creator unknown, provenance Sweden, with thanks to Gunbritt Sandström, Roger Sellgren, with special thanks to Jane Mears and to Gail Carnes.

As Lisa Bjurwald has written, "Swedes ... like to keep a remarkably wide so-called interpersonal distance." This is evident in this deceptively simple but brilliant meme, which so economically encapsulates the unwritten rule regarding appropriate Swedish socio-spatial proximity.

\section{THE RELATIONSHIP BETWEEN HUMOUR AND LAUGHTER IN RELATION TO THIS PANDEMIC}

There is another side to the coin, too, that has potential ramifications for this article, but is equally valid for all humour. Zhao et al. have demonstrated through wide-ranging research on adults quantifying the effects of humour and laughter, also taking into account the quality of sleep, "that laughter and humour interventions are effective in relieving depression, anxiety, and improve sleep quality in adults" (2435). Their research project, which involved 814 people in ten studies, "showed that . . . [humour and laughter] significantly decreased adults' depression, anxiety, and improved their sleep quality. The results of subgroup analysis showed that 
depression benefits more from long-term laughter intervention” (2435). At this time of confusion and major changes in people's routines resulting from this deadly pandemic, the importance of such research shouldn't be underestimated.

During this current crisis humour is our indispensable ally. While jokes and humour have the capacity to divide, by attacking other people's cherished beliefs, they also have the power to bind us more closely.

\section{CONCLUSION}

Love it or loathe it, for many people globally the internet has been, for the most part, a liberating force during this prolonged time of confinement. The fact is that in the absence of our usual face-to-face interactions, aside from our immediate families or loved ones-from whom we may now sometimes feel we need a break-online humour, absurdity and wit, along with cartoons or memes revealing the nonsense and grotesquery on the part of our Dear Leaders act as a source of minor, temporary, salvation. We laugh when authoritarian bureaucrats and self-admiring politicians set themselves above us, because in doing so they also set themselves above common sense in their handling of this deadly pandemic.

In terms of the most significant styles of humour that are at play during the COVID-19 epoch (success being gauged by the extent that any humorous discourse that distracts us from the pandemic's downside has an upside), this study indicates that the various psychological explanations of humour-relief, release and catharsis—spliced onto existential humour and the incongruity theory seem the most relevant. The best coronavirus humour provides people with light-hearted fun; brief interludes in otherwise virtually indistinguishable days for those of us who are housebound and waiting.

Our collective condition of waiting brings to mind Samuel Beckett's tragi-comic masterpiece Waiting for Godot (En attendant Godot), itself a work of existential humour. This is a dark humour that resonates with our current collective human condition during the pandemic. In this play two tramps, Vladimir and Estragon, are waiting for a man called Godot, who never turns up. Day after day while waiting for something to happen the pair engages in banter; they quarrel; they urinate; they take off their shoes and hats; they put them back on again; they spend time musing on metaphysical topics. Every now and then a boy comes to tell the pair that Godot won't be coming on that day. It is uncertain that Godot even exists. The meaning, absurdity, and lack of intrinsic purpose of human life are traversed in this play, but nevertheless Vladimir and Estragon continue to 
wait ... and wait for Godot ... but their hopes are never realized. While we, absurdly self-described as homo sapiens, wait for the coronavirus pandemic to go.

\section{Works Cited}

Anderson, Benedict. Imagined Communities: Reflections on the Origin and Spread of Nationalism. London: Verso, 1983. Print.

Bakhtin, Mikhail. Speech Genres and Other Late Essays. Trans. Vern W. McGee.

Ed. Caryl Emerson and Michael Holquist. Austin: U of Texas P, 1986. Print. Beckett, Samuel. En attendant Godot. Paris: Minuit, 1952. Print.

Betcher, R. William. "Intimate Play and Marital Adaptation." Psychiatry 44

(1981): 13-33. Print. https://doi.org/10.1080/00332747.1981.110240 88; PMid:27755884

Bienkov, Adam. "Scientists Fear the Hunt for a Coronavirus Vaccine Will Fail and We Will All Have to Live with the 'Constant Threat' of COVID-19.” Businessinsider.com.au. Business Insider Australia 25 Apr. 2020. Web. 25 Apr. 2020.

Bjurwald, Lisa. "Social Distance, Swedish style." Politico.eu. Politico 30 Mar. 2020. Web. 20 Apr. 2020.

Blackmore, Susan. The Meme Machine. London: Oxford UP, 1999. Print. Boston, Richard. An Anatomy of Laughter. London: Collins, 1974. Print. Bremmer, Jan N., and Herman Roodenburg. A Cultural History of Humour: From Antiquity to the Present Day. Cambridge: Polity, 1997. Print.

Camus, Albert. La peste. Paris: Gallimard, 1947. Print.

Camus, Albert. Le mythe de Sisyphe. Paris: Gallimard, 1942. Print.

Camus, Albert. The Myth of Sisyphus. Trans. Justin O'Brien. London: Penguin Classics. 1955. Print.

Camus, Albert. The Plague. Trans. Stuart Gilbert. Harmondsworth: Penguin, 1960. Print.

Coleridge, Samuel Taylor. Biographia Literaria. Gutenberg.org. Project Gutenberg Jul. 2004. Web. 3 Aug. 2020.

"Coronavirus: Outcry after Trump Suggests Injecting Disinfectant as Treatment." Bbc.com. BBC 24 Apr. 2020. Web. 25 Apr. 2020.

Clark, Michael. "Humour and Incongruity." Philosophy 45.171 (1970): 20-32. Print. https://doi.org/10.1017/S003181910000958X

Davies, Christie. Jokes and Targets. Bloomington: Indiana UP, 2011. Print. Dawkins, Richard. The Selfish Gene. Oxford: Oxford UP, 1976. Print.

Dayan, Daniel, and Elihu Katz. "Media Events: On the Experience of Not Being There.” Religion 15.3 (1985): 305-14. Print. https://doi. org/10.1016/0048-721X(85)90017-X 
Dayan, Daniel. Media Events: The Live Broadcasting of History. Cambridge: Harvard UP, 1992. Print.

Deutsch Presse-Agentur (DPA). "Americans Follow Trump 'Advice' by Gargling Bleach." The Australian Nerespaper 8 Jun. 2020: 8. Print.

de Waal, Frans. Are We Smart Enough to Know How Smart Animals Are? UK: Granta, 2016. Print.

Eagleton, Terry. Humour. US Office: Yale UP, 2019. Print. https://doi. org $/ 10.2307 / j . c t v f c 528 \mathrm{q}$

"Family, Domestic and Sexual Violence in Australia." Aibre.giv.au. Australian Institute of Health and Welfare 15 May 2019. Web. 19 Oct. 2019.

Farmer, Blake. "At Least 9,000 U.S. Health Care Workers Sickened With COVID-19, CDC Data Shows." Npr.org. Nashville Public Radio 15 Apr. 2020. Web. 20 May 2020.

Francis, Adrian. Personal communication with the author. 17 Jun. 2020.

Freud, Sigmund. Jokes and their Relation to the Unconscions. The Standard Edition of the Complete Psychological Works of Sigmund Frend. Volume VIII. London: Hogarth/The Institute of Psycho-Analysis, 1953/1974. Print.

Fromkin, Victoria A. "Slips of the Tongue." Scientific American 229 (Dec. 1973): 181-86. Print. https://doi.org/10.1038/scientificamerican 1273-110; PMid:4756435

Georges, Robert A., and Alan Dundes. "Toward a Structural Definition of the Riddle." The Journal of American Folklore 76.300 (1963): 111-18. Print. https://doi.org/10.2307/538610

Ginsburg, Kenneth R., the Committee on Communications, and the Committee on Psychosocial Aspects of Child and Family Health. "The Importance of Play in Promoting Healthy Child Development and Maintaining Strong Parent-Child Bonds.” Pediatrics 119.1 (Jan. 2007): 182-91. Web. 6 Aug. 2020. https://doi.org/10.1542/peds.2006-2697

Glendinning, Phil. "Asylum Seekers, Refugees and Human Dignity.” Social Alternatives 34.1 (2015): 27-33. Print.

Glez, Damien. "[Chronique] Top 10 des bénéfices inattendus du coronavirus." Jeuneafrique.com. Jeune Afrique 26 Mar. 2020. Web. 30 Mar. 2020.

Groos, Karl. The Play of Man. Trans. Elizabeth L. Baldwin. New York: D. Appleton, 1912. Print.

Groos, Karl. “The Psychology of Animal Play.” The Play of Animals. Trans. Elizabeth L. Baldwin. New York: D. Appleton, 1898. 287-328. Print.

Haastrup, Helle Kannik. "One Re-Enchanted Evening: The Academy Awards as a Mediated Ritual within Celebrity Culture." Northern Lights: Film and Media Yearbook 6.1 (2008): 127-42. Print. https:// doi.org/10.1386/nl.6.1.127_1 
Halfpenny, Kate. "Winnie the Pooh Banned in China over Comparisons to President Xi." Thenewdaily.com.au. New Daily 7 Aug. 2018. Web. 31 May 2020.

Holland, Norman N. “The 'Willing Suspension of Disbelief' Revisited.” The Centennial Review 11.1 (1967): 1-23. Print.

Hunter, David J. Essentials of Discrete Mathematics. Burlington, MA: Jones and Bartlett, 2011. Print.

Jackson, David. "Trump Says Schools Should Reopen Because Children Are 'Virtually Immune.” Usatoday.com. USA Today 5 Aug. 2020. Web. 7 Aug. 2020.

Kessler, Glenn. "Trump's Claim That 99\% of Coronavirus Cases Are Totally Harmless." Washingtonpost.com. The Washington Post $8 \mathrm{Jul}$. 2020. Web. 20 Jul. 2020.

Knight, Charles A. The Literature of Satire. Cambridge: Cambridge UP, 2004. Print. https://doi.org/10.1017/CBO9780511485428

Kollwitz, Kath. Personal communication with the author. 3 Jun. 2020

Kuipers, Giselinde. Good Humor, Bad Taste: A Sociology of the Joke. Berlin: Walter de Gruyter, 2015. Print. https://doi.org/10.1515/ 9781501510441

Lintern, Shaun. “Coronavirus: Medics Shouldn't Work without Safe PPE, Doctors Told as Fears Grow UK Pandemic Stockpile Is Almost Empty." Independent.co.uk. Independent 20 Apr. 2020. Web. 20 Apr. 2020.

Malley, Robert. "Continuing with the Status Quo Offers Only the Prospect of Endless War. 10 Conflicts to Watch in 2020." Crisisgroup. org. International Crisis Group 27 Dec. 2019. Web. 3 Jul. 2020.

McGrew, May. Rev. of The Meme Machine, by Susan Blackmore. PaleoAnthropology 1 (2003): 23-24. Print.

Milner Davis, Jessica. “'Aussie' Humour and Laughter: Joking as an Acculturating Ritual." Serious Frolic: Essays on Australian Humour. Ed. Frances De Groen and Peter Kirkpatrick. Queensland: U of Queensland P, 2009. 31-47. Print.

Milner Davis. Personal communication with the author. 12 May 2020.

Mrowa-Hopkins, Colette. Personal communication with the author. 3 Jul. 2020.

Nash, Walter. The Language of Humour. London: Longman, 1985. Print.

Nilsen, Don L. F. "The Importance of Tendency: An Extension of Freud's Concept of Tendentious Humor." Humor: International Journal of Humor Studies 1 (1988): 335-47. Print. https://doi.org/10.1515/ humr.1988.1.4.335

Norrick, Neal R. "Intertextuality in Humor." Humor 2.2 (2009): 117-140. Web. 20 May 2020. https://doi.org/10.1515/humr.1989.2.2.117 
Orthner, Dennis K. "Leisure Activity Patterns and Marital Satisfaction over the Marital Career." Journal of Marriage and Family 37 (1975): 91-102. Print. https://doi.org/10.2307/351033

Orthner, Dennis K. "Patterns of Leisure and Marital Interaction." Journal of Leisure Research 8 (1976): 98-111. Print. https://doi.org/10.1080/002222 16.1976.11970261

Osaki, Tomohiro. "Abenomask? Prime Minister's 'Two Masks per Household' Policy Spawns Memes on Social Media." Japantimes.co.jp. Japan Times 2 Apr. 2020. Web. 16 Jun. 2020.

Pansy the Dancing Horse. Amy Savarese. Online video clip. Vimeo.com. Vimeo 5 Dec. 2015. Web. 20 May 2020.

Połońska-Kimunguyi, Eva, and Marie Gillespie. "Terrorism Discourse on French International Broadcasting: France 24 and the Case of Charlie Hebdo Attacks in Paris." European Journal of Communication 31.5 (2016): 568-83. Print. https://doi.org/10.1177/0267323116669453

Provine, Robert. "Contagious Laughter: Laughter is a Sufficient Stimulus for Laughs and Smiles." Bulletin of the Psychonomic Society 30.1 (1992): 1-4. Print. https://doi.org/10.3758/BF03330380

Rabin, Roni Caryn, and Chris Cameron. "Trump Falsely Claims '99 Percent' of Virus Cases Are 'Totally Harmless."' Nytimes.com. The New York Times 5 Jul. 2020. Web. 5 Jul. 2020.

Rand, Ayn. Atlas Shrugged. New York: Random, 1957. Print.

Rose, Jacqueline. "Pointing the Finger." London Review of Books 42.9 (2020): n.p. Lrb.co.uk. Web. 2 Jun. 2020.

Rose, Margaret A. Pictorial Irony, Parody, and Pastiche: Comic Interpictoriality in the Arts of the $19^{\text {th }}$ and $20^{\text {th }}$ Centuries. Bielefeld: Aisthesis Verlag, 2011. Print.

Sandford, Alasdair, and Luke Hurst. "Boris Johnson Grilled on 'Vague' UK Coronavirus Lockdown Advice." Euroneres.com. Euronews 12 May 2020. Web. 15 May 2020.

Shaftesbury (Earl of), Anthony Ashley Cooper. Sensus Communis: An Essay on the Freedom of Wit and Humour. In a Letter to a Friend. UK: Gale Ecco, 2018. Print.

Sherzer, Joel. "Puns and Jokes." Handbook of Discourse Analysis: Discourse and Dialogue. Ed. Teun A. Van Dijk. London: Academic, 1985. 213-21. Print.

Shifman, Limor. "Memes in a Digital World: Reconciling with a Conceptual Troublemaker." Journal of Computer-Mediated Communication 18.3 (2013): 362-77. Print. https://doi.org/10.1111/jcc4.12013

Suls, Jerry M. "A Two Stage Model for Appreciation of Jokes and Cartoons: An Information-Processing Analysis." The Psychology of Humor: Theoretical Perspectives and Empirical Issues. Ed. Jeffrey H. Goldstein and Paul E. McGhee. New York: Academic, 1972. 81-100. Print. https://doi.org/10.1016/B978-0-12-288950-9.50010-9 
Timms, Peter. Silliness: A Serious History. South Australia: Wakefield, 2019. Print.

Totilo, Stephen. "When a Gaming Fantasy Is Eerily Close to Reality." Nytimes.com. The New York Times 8 Apr. 2020. Web. 11 Apr. 2020.

Turak, Natasha. "Wearing a Mask Can Significantly Reduce Coronavirus Transmission, Study on Hamsters Claims." Cnbc.com. CNBC (Consumer News and Business Channel) 19 May 2020. Web. 20 May 2020.

Veale, Tony. "Strategies and Tactics for Ironic Subversion." Developments in Linguistic Humour Theory. Topics in Humour Theory 1. Ed. Marta Dynel. Amsterdam: John Benjamins, 2013. 321-40. Print. https://doi. org/10.1075/thr.1.15vea

Weber, Caroline. "Fasion [sic]." Nytimes.com. The New York Times 3 Dec. 2006. Web. 20 May 2020.

Zhao, Jinping, et al. "A Meta Analysis of Randomized Controlled Trials of Laughter and Humour Interventions on Depression, Anxiety and Sleep Quality in Adults.” Journal of Advanced Nursing 75 (2019): 2435-48. Print. https://doi.org/10.1111/jan.14000; PMid:30882915

\section{Christine Nicholls is an Honorary Senior Lecturer at} the Australian National University, Canberra. She has been published in diverse areas including visual art, sociolinguistics, anthropologically-related topics, literature (including children's literature), biography, information visualization and education. She has written more than 20 books for adults and children, published by commercial publishers, with many winning national prizes. For 14 years she was the Australian Contributing Editor of Asian Art Neres and World Sculpture Nerws (Hong Kong). A good deal of her writing has been influenced by the time she spent working at Lajamanu, a remote Aboriginal settlement in Australia's Central Desert. Over the years she has had a strong online presence, including writing for The Conversation, and writing reviews and obituaries for various Australian newspapers.

This is her second humour-related article, with the first focussing on Warlpiri (Aboriginal) nicknaming practices. Currently she is writing a book on humour and rhetoric.

ORCID: 0000-0002-2470-2512

christine.nicholls@anu.edu.au 